\title{
Media Self-regulation through Media Literacy: Insights from the Cebu Citizens-Press Council (CCPC) ${ }^{1}$
}

\author{
Ma. Theresa Angelina Q. Tabada
}

How does the press regulate itself? Through document research, key informant interviews, and participant observation, the researcher studied how the Cebu Citizens-Press Council (CCPC) promotes media self-regulation (MSR) among the Cebu press and media literacy (ML) among citizens and netizens in Cebu, a metropolis in southern Philippines. Led by civil society leaders, the editors-in-chief of Cebu newspapers, and other media leaders, the CCPC conducts MSR through the reactive mechanism of adjudicating complaints about accuracy and fairness or right of reply raised against Cebu's five local newspapers. Its proactive mechanism involves the promotion of MSR among local journalists and the initiation of ML for citizens and netizens. MSR thrives in a setting that involves four stakeholders: newspapers, media advocacy groups, citizens, and netizens, and it can be enhanced and sustained through $\mathrm{ML}$, which ensures greater participation of citizens and netizens as media watchdogs and defenders of freedom of expression.

Keywords: Media self-regulation, media literacy, citizens-press council, media watchdogs, press freedom

This study of the Cebu Citizens-Press Council (CCPC) reveals that media selfregulation thrives in a setting that involves four stakeholders: newspapers, media advocacy groups, citizens, and netizens. But understanding the role of the press in a democracy begins with knowing that this self-regulation begins with each journalist and is reinforced by the newsroom he or she is a member of. The foundations of ethics, inculcated in a journalist's personal background and formal training, are reinforced by a newsroom's internal policies and processes for accountability.

This study establishes that aside from implementing mechanisms for answerability or responsiveness to complaints and other feedback from the audience, Cebu print newsrooms have other accountability measures: the code of ethics and standards such as Cebu Daily News's "Canons of Taste for Journalists" and the Sun.Star Code of Standards and Ethics; daily editorial news conference where the editorial board reviews all the news stories before publication in order to eliminate or at least minimize bias in news reports; regular critiquing sessions among fellow online editors, as conducted by 
the Sun.Star Network Exchange (SUNNEX); an internal ombudsman (for Sun.Star Cebu and Sun.Star Superbalita Cebu) or a readers' advocate (for Cebu Daily News), who checks the accuracy of reports and spots potential biases in news stories; a public and standards editor (for Sun.Star Cebu and Sun.Star Superbalita Cebu), who orients the public on how the press works through newspaper columns on media literacy such as "Media's Public," the regular column of Sun.Star public and standards editor Pachico A. Seares; online feedback mechanisms such as the creation of the posts of social media editor (for Sun.Star Cebu), network exchange coordinator (SUNNEX), and multimedia coordinator (for Cebu Daily News), who monitor audience feedback on social media and post corrections in the Content Management System (CMS) of the news website; and the support of media advocacy groups such as the Cebu Citizens-Press Council (CCPC), Cebu Media Legal Aid (CEMLA), and Cebu Federation of Beat Journalists (CFBJ). Thus, the professional culture within a newsroom is clearly the direct institutional setting that nurtures a culture of self-regulation among journalists.

\section{Historical and Institutional Setting of Media Self-regulation (MSR) in Cebu}

\section{Newsrooms}

In the five Cebu newsrooms studied for this paper, key informants said that editors were the ones who performed the gatekeeping functions by staying vigilant and not letting articles that serve the personal agenda of a reporter and his or her patron, rather than the public good, slip. When an editor spots the so-called "badges of prostitution or coercion" (Seares, 2013, p. 21), which give away the reporter's compromise of journalism and standards, or when there is a complaint against reportorial or editorial bias, the newspapers implement a process to investigate the complaints and pass sanctions.

For some community papers characterized by small newsrooms serving small communities, the professional discipline of ethics and standards is reinforced by a culture of stakeholdership. Some community journalists see their membership in the community they cover as shaping their news work and sense of imagined community or connectivity to the community. However, contrary to Bill Reader's 2006 findings that the size of the newsroom and community affect a journalist's application of normative and situational ethics, some community journalists in Cebu view self-regulation as purely a professional responsibility since their newsrooms do not overtly adopt a policy and culture of community advocacy. 
Table 1 summarizes the six ways the five Cebu newspapers respond to citizens' complaints and other forms of feedback, in keeping with the accountability principle of media self-regulation and social responsibility.

Table 1. Accountability mechanisms in Cebu newspapers.

Ways Cebu Newspapers Respond to Citizens' Complaints and Other Feedback

1. A newsroom creates and enforces a code of standards and ethics, such as the Cebu Daily News's "Canons of Taste for Journalists" and the Sun.Star Code of Standards and Ethics.

2. A newsroom conducts daily editorial news conference where the editorial board reviews all the news stories before publication to eliminate or at least minimize the entry of bias in news reports. Another newsroom practice is to hold regular critiquing sessions among fellow online editors, as conducted by the Sun.Star Network Exchange (SUNNEX).

3. A newsroom appoints an internal ombudsman (Sun.Star Cebu and Sun.Star Superbalita Cebu) or readers' advocate (Cebu Daily News), who checks the accuracy of reports and who spots potential biases in news stories. Media self-regulation and media literacy are carried out by the newsroom's public and standards editor, who addresses issues concerning journalism standards with journalists and the public. Media literacy columns such as "Media's Public," the regular column of Sun.Star public and standards editor Pachico A. Seares, explain how a newspaper covers and treats news.

4. Following its policy and process of answerability, a newsroom publishes an erratum and corrects the error; publishes a follow-up article that airs the side of the complainant; explains in an article how editorial decisions were arrived at; and publishes the complaint in the Op-Ed pages, among other responses.

5. A newsroom responds to online feedback by creating the posts of social media editor (Sun.Star Cebu), network exchange coordinator (SUNNEX), and multimedia coordinator (Cebu Daily News), who monitor audience feedback on social media and post corrections in the Content Management System (CMS) of the news website; connecting netizens with editors and other netizens; tapping social networks; and using other new media tools for community engagement and interactivity.

6. A newspaper supports and cooperates with CCPC and other media advocacy groups such as the Cebu Citizens-Press Council (CCPC), Cebu Media Legal Aid (CEMLA), and Cebu Federation of Beat Journalists (CFBJ).

\section{Media Advocacy Groups}

The Philippine press has a history of applying the accountability mechanism of the press council, another mechanism promoting journalistic ethics and professionalism (Bengco, 2011). At the national level, there are two existing press councils: the Philippine Press Council (PPC), founded by the Philippine Press Institute (PPI), whose members are "the major national and provincial daily/weekly newspapers in the country" ("About the PPI," n.d., para. 3); and the Broadcast Standards Authority of the Kapisanan ng mga Brodkaster ng Pilipinas (KBP or the Association of Broadcasters of the Philippines), which promotes "professional and ethical standards" 
(Kapisanan ng mga Brodkaster ng Pilipinas, n.d., para. 1) among the station owners, operators and news staff of its radio and television members.

In accordance with Section 3 of Republic Act 4363, which was enacted on June 19, 1965, the PPC was formed to "promulgate a Code of Ethics, investigate violations, and censure any journalist or newspaper guilty of violating the Code" (Bengco, 2011, para. 5).

In 1972, after proclaiming martial law, President Ferdinand Marcos closed down the PPI and PPC, replacing them with the Mass Media Council (MMC) then the Media Advisory Council (MAC) in 1973, and then the Philippine Council for Print Media (PCPM) and the Philippine Council for Broadcast Media (PCBM) in 1974 (Bengco, 2011). These government bodies were tasked to regulate media and safeguard the state from the manipulation of the press by "forces of insurgency and subversion" (Bengo, 2011, para. 6) presented by the Left and the oligarchy.

However, the Marcos government's regulation was, in practice, control of the media. "During the martial law years, corruption was rampant and cronyism was at its peak. The press was severely controlled and repressed through a score of regulation" (Article 19 \& CMFR, 2005, p. 10). At the start of martial law, MAC censors, military men or government lawyers literally sat beside the editor and read the copy before an article saw print (Pinlac, 2007). Only papers owned by cronies, such as Roberto Benedicto's Philippine Daily Express, and Hans Menzi's Manila Bulletin, were spared the censors' visits. Government regulation led to self-censorship among many reporters and editors wary of publishing anything that could be interpreted as expressing "arrogance towards the Marcos government" (para. 9). Those who deviated from the guidelines issued by the Malacañang Press Office on what to publish and what not to were slapped with libel suits or salvaged, that is, assassinated (para. 28).

After Marcos was driven from power by the People Power Revolution in February 1986, the PPI was reactivated. Initially, Manila newspaper publisher-owners tasked press ombudsmen or readers' advocates to receive complaints and train newsroom staff on ethics and standards (Miranda, 2002a). In 1988, the PPI convened the different Manila newspapers' press ombudsmen and recommended the creation of a press council (Miranda, 2002a, p. 37).The PPI "formally founded" the PPC in 1993. The following two decades saw the PPC undergo several challenges in implementing media self-regulation and accountability, particularly in guaranteeing a news subject's right of reply-the PPC's primary function (Bengco, 2011).

The PPI is unique in Asia for not being initiated by the government. It is the print industry's accountability mechanism for practicing self-regulation (Bengco, 2011). However, the scope of its regulation covers only member 
newspapers. At the time of Regina Bengco's 2011 study of the PPC, "only six out of 10 national newspapers/newspaper groups in the country," were PPC members. The PPC faces other challenges in implementing accountability: the public's lack of awareness of the PPC's existence and role, the fear preventing the aggrieved from complaining against the media, and the difficulty in terms of time and resources for a Metro Manila-based press council to receive and act on complaints from communities outside of Metro Manila.

Aside from the "fundamental fairness" of voluntarily granting news subjects the right of reply, the PPC sought to educate member newspapers that it was in their "best interest to present all sides to a story at once" (Mariano, 2002, p. 67) because it is also a means to "increase (the papers') credibility" (p. 67) and "decrease their susceptibility to court action" (p. 67). Prior to the 1998 presidential election, the PPI adopted its Code of Professional and Ethical Conduct, which it disseminated for adoption to its member newspapers and other media bodies. The PPC held the Editors Forum where resource persons discussed with PPC members and alternates to respond to the "incompetence, ignorance and laziness," perceived as "big a threat to press freedom as corruption" (p. 70).

In 2000, the PPC was opened to non-journalists for membership. Members of the academe, the law profession, and the business sector were invited to prevent the PPC from becoming an "old boys network, a tiny self-congratulating clique that could lose its sensitivity to delicate ethical questions and its sense of urgency to take action on them" (Mariano, 2002, p. 71). Also planned were collaborations with journalism schools and media watchdogs since, in keeping with the PPI Code of Professional and Ethical Conduct, the PPC believes that "it takes a community of journalists" to turn the code into the "genuine, positive, powerful norm and standard that it should be for the country" (Mariano, 2002, p. 72) .

Another national media advocacy group is the Center for Media Freedom and Responsibility (CMFR). Established in 1989, the CMFR is a "private, non-stock and non-profit organization involving the different sectors in the task of building up the press and other news media as a pillar of democracy" (Katigbak, 2002, p. 102). It publishes the PJR, a "professional journal that monitors the performance of the press and identifies the problematic areas of coverage" (p. 102). This media watchdog is distributed to "over 500 journalists in the country, and is also used as instructional material for the teaching of journalism ethics in colleges and universities" (p. 102).

The CMFR and other media advocacy groups are post-martial law responses, indicating "a growing realization within the profession of the need for self-evaluation and self-regulation in a democratizing society" 
(Article 19 \& Center for Media Freedom and Responsibility, 2005, p. 66). The CMFR helped establish citizens press councils (CPCs) in Cebu, Baguio and Palawan as it "has always seen freedom and responsibility as linked" (De Jesus \& Khan, 2005, p. 15). In the study, "In search of solutions: A study of journalist killings in the Philippines, 2000-2005" (p. 15), the CMFR identified the role of an "invigorated press council that includes civil society members in promoting press accountability" (p. 15)making the grievance process "more accessible," and providing a "public forum for the discussion of media and related issues" (p. 15).

Given the rising number of journalists killed "in the line of duty" since 1991 (when CMFR began its database on the killings) and the culture of impunity in the country, the CMFR observed in the same report that a "more civil media and a press orientation toward genuine public service might help to temper the resort to violence in Philippine society" (De Jesus \& Khan, 2005, p. 15). Shiela Coronel (in De Jesus \& Khan, 2005), Philippine Center for Investigative Journalism (PCIJ) executive director, also proposed media self-regulation as one way to stop the killings. In the PCIJ blog, she posted, "Should part of the protection work include fortifying the quality of journalism to make it less vulnerable to violent attack?” (p. 15).

Based on documentation of the history of Cebu media and the feedback of selected representatives of the public and media sectors, this study notes that Cebu print newsrooms (i.e., Banat News, Cebu Daily News, Sun.Star Cebu, Sun.Star Superbalita Cebu, and The Freeman) and media advocacy groups have been active for decades in media self-regulation and more recently, media literacy. In these initiatives, the PPI and the CMFR are active partners of Cebu colleagues. For about three decades, media advocacy groups operated informally and then formally in Cebu (Tabada, 2015). According to the 22-year timeline of the Cebu Press Freedom Week, media advocacy groups since1984 have gathered for a week in September (to coincide with the anniversary of martial law, which was September 21, 1972) to commemorate the importance of upholding and protecting press freedom (Cuizon, 2014).

Initially, Cebu print journalists organized to present a common stance and line of defense against external threats: politicians, rogue elements in the military, anti-communist crusaders, and martial law. Print journalists organized formally, forming the Association of Cebu Journalists, Cebu News Workers Multipurpose Cooperative (Cebu News Coop), Cebu News Correspondents Club, Council of Cebu Media Leaders (CCML), Cebu News Workers Foundation (CENEWOF), Cebu Federation of Beat Journalists (CFBJ), CCPC, Cebu Media Legal Aid (CEMLA), and Cebu Press Freedom Week Inc (CPFWI) (Tabada, 2015). Other journalists grouped informally 
due to personal bonding and shared vision-as in the case of the all-women group STET_-or shared work, as in CFBJ's membership of 11 beat reporters' organizations (Tabada, 2015).

Table 2 shows, in alphabetical order, the media advocacy groups and other entities, highlighting the interplay of advocacies to promote media self-regulation and media literacy in Cebu.

Table 2. Cebu media advocacy groups and other entities.

\begin{tabular}{|c|c|c|}
\hline $\begin{array}{c}\text { Media } \\
\text { Advocacy } \\
\text { Group }\end{array}$ & Profile & Highlights \\
\hline $\begin{array}{l}\text { Cebu } \\
\text { Federation } \\
\text { of Beat } \\
\text { Journalists } \\
\text { (CFBJ) }\end{array}$ & $\begin{array}{l}\text { • "Aims to foster unity } \\
\text { among beat reporters" and } \\
\text { photographers of Cebu print } \\
\text { and broadcast outlets } \\
\text { - Composed initially of seven, } \\
\text { later } 11 \text { beat-based groups of } \\
\text { reporters: } \\
\text { a) Media Alliance for the Law, } \\
\text { Liberty, Equality and Truth } \\
\text { (MALLET): courts } \\
\text { b) Capitol Association of } \\
\text { Reporters in Tri-Media } \\
\text { (CART) } \\
\text { c) City Hall Association of } \\
\text { Reporters in Media } \\
\text { (CHARM): Cebu City Hall } \\
\text { d) Regional Journalists in Cebu } \\
\text { (REJOICE): regions } \\
\text { e) Association of Reporters in } \\
\text { Mandaue and Lapu-Lapu } \\
\text { City in Truth and Excellence } \\
\text { (ARMALITE) } \\
\text { f) Media in Cebu South (MIS) } \\
\text { g) Defense and Police Press } \\
\text { Corps (DEPP) } \\
\text { h) Entertainment Group } \\
\text { (E-Group) } \\
\text { i) Cebu Economic Journalists } \\
\text { Association (CEJA) } \\
\text { j) Sports Correspondents } \\
\text { (SCORE) } \\
\text { k) LENS: photojournalists }\end{array}$ & $\begin{array}{l}\text { - Organized during the 6th } \\
\text { CPFW on Sept. 17-23, } 2000 \\
\text { (a) Sun.Star Cebu hosts pre- } \\
\text { assembly meetings of beat } \\
\text { groups } \\
\text { (b) CENEWOF hosts the } \\
\text { general assembly } \\
\text { - With Sun.Star Cebu, "laid } \\
\text { the groundwork" for the } \\
\text { reactivation of the CCPC in } \\
2005 \\
\text { - Co-organizes CPFW activities } \\
\text { - Undertakes activities } \\
\text { throughout the year }\end{array}$ \\
\hline
\end{tabular}




\begin{tabular}{|c|c|c|}
\hline $\begin{array}{l}\text { Media } \\
\text { Advocacy } \\
\text { Group }\end{array}$ & Profile & Highlights \\
\hline & $\begin{array}{l}\text { - Considered as the "biggest } \\
\text { media organization in the } \\
\text { country's south" }\end{array}$ & \\
\hline $\begin{array}{l}\text { Cebu } \\
\text { Citizens- } \\
\text { Press } \\
\text { Council } \\
\text { (CCPC) }\end{array}$ & $\begin{array}{l}\text { - Initiated in } 2001 \text { by editors-in- } \\
\text { chief of Cebu Daily News, Sun. } \\
\text { Star Cebu and The Freeman } \\
\text { - Assisted by the Philippine } \\
\text { Press Council (PPC) and the } \\
\text { Center of Media Freedom and } \\
\text { Responsibility (CMFR) } \\
\text { - Went into "hibernation" for } \\
\text { three years } \\
\text { - Reactivated in } 2005 \\
\text { - Registered with the Securities } \\
\text { and Exchange Commission } \\
\text { (SEC) as a nonstock, nonprofit } \\
\text { organization } \\
\text { - } 15 \text { members representing Cebu } \\
\text { print media, business, academe, } \\
\text { church, and civil society }\end{array}$ & $\begin{array}{l}\text { - Initiated during the 7th CPFW } \\
\text { on Sept. 16-22, 2001, with } \\
\text { discussions for setting up a } \\
\text { Citizens' Press Complaint Board } \\
\text { - Held the first working session } \\
\text { during the 8th CPFW on Sept. } \\
\text { 15-21, } 2002 \\
\text { - Conducted the meeting } \\
\text { reactivating the 15-member } \\
\text { council during the } 11 \text { th CPFW } \\
\text { in } 2005 \\
\text { - Partners with CENEWOF, } \\
\text { CFBJ, CEMLA and other media } \\
\text { advocacy groups } \\
\text { - Undertakes activities } \\
\text { throughout the year }\end{array}$ \\
\hline $\begin{array}{l}\text { Cebu } \\
\text { Journalism } \\
\text { \& Journalists } \\
\text { (CJJ) }\end{array}$ & $\begin{array}{l}\text { - First issue titled Cebu } \\
\text { Journalism: The People and the } \\
\text { Times } \\
\text { - Annual yearbook recording } \\
\text { the legitimate members of } \\
\text { Cebu working press and issues } \\
\text { affecting ethics, standards, } \\
\text { and practices of journalism, } \\
\text { particularly the community } \\
\text { press } \\
\text { "(M)odest goal... (to) be of } \\
\text { some use to the few people } \\
\text { who might care Cebu } \\
\text { journalism's history" } \\
\text { - Distributed for free to schools, } \\
\text { government, companies, and } \\
\text { other institutions in the nation }\end{array}$ & $\begin{array}{l}\text { - Cebu Daily News, Sun.Star Cebu } \\
\text { and The Freeman ran articles } \\
\text { on "icons" of Cebu journalism } \\
\text { during the 9th CPFW in } 2003 \\
\text { and 10th CPFW in } 2004 \text { to } \\
\text { introduce students and refresh } \\
\text { media professionals on models } \\
\text { to emulate in journalism } \\
\text { - First issue published during } \\
\text { the } 2004 \text { CPFW } \\
\text { - Publication timed during the } \\
\text { CPFW } \\
\text { - Conceptualized and } \\
\text { supervised by Pachico A. } \\
\text { Seares and written and edited } \\
\text { by Sun.Star Cebu reporters and } \\
\text { editors } \\
\text { E-book version of CJJ } 7 \\
\text { released during the 18th CPFW } \\
\text { in } 2012\end{array}$ \\
\hline
\end{tabular}




\begin{tabular}{|c|c|c|}
\hline $\begin{array}{l}\text { Media } \\
\text { Advocacy } \\
\text { Group }\end{array}$ & Profile & Highlights \\
\hline $\begin{array}{l}\text { Cebu Media } \\
\text { Legal Aid } \\
\text { (CEMLA) }\end{array}$ & $\begin{array}{l}\text { - Convened by five lawyer- } \\
\text { journalists to give pro } \\
\text { bono counsel to journalists } \\
\text { charged with libel and other } \\
\text { complaints Complements } \\
\text { the legal assistance given by } \\
\text { media companies to journalist- } \\
\text { employees }\end{array}$ & $\begin{array}{l}\text { - During Dec. 5, } 2006 \text { CCPC } \\
\text { meeting, nine lawyers joined } \\
\text { CEMLA } \\
\text { - In 2012, partners with CCPC } \\
\text { and the Integrated Bar of the } \\
\text { Philippines (IBP) } \\
\text { - Cebu City and Cebu chapters } \\
\text { started "database for court } \\
\text { decisions on libel and } \\
\text { contempt and legal articles of } \\
\text { media law" } \\
\text { - Legal adviser of CCPC } \\
\text { - Undertakes activities } \\
\text { throughout the year }\end{array}$ \\
\hline $\begin{array}{l}\text { Cebu Media } \\
\text { Medical } \\
\text { Aid Fund } \\
\text { (CEMMAF) }\end{array}$ & $\begin{array}{l}\text { - Channels medical assistance } \\
\text { to media workers (primary } \\
\text { beneficiaries) and their } \\
\text { legitimate families (secondary } \\
\text { beneficiaries). Health benefits } \\
\text { cover cost of hospitalization, } \\
\text { maintenance medicine, } \\
\text { laboratory tests and } \\
\text { procedures } \\
\text { - Other programs cover } \\
\text { assistance to public } \\
\text { elementary, high school } \\
\text { and college graduating } \\
\text { students, burial assistance, } \\
\text { disaster management such } \\
\text { as disaster relief, emergency } \\
\text { shelter, disaster preparedness } \\
\text { trainings, self- defense, and } \\
\text { health awareness for primary } \\
\text { and secondary beneficiaries }\end{array}$ & $\begin{array}{l}\text { - Initial trust fund raised by } \\
\text { media } \\
\text { - In 2006, seed money raised } \\
\text { from P2-million Priority } \\
\text { Development Assistance } \\
\text { Fund (PDAF) of Rep. Raul del } \\
\text { Mar (Cebu City, first district) } \\
\text { and P1-million PDAF of Rep. } \\
\text { Antonio Cuenco (Cebu City, } \\
\text { second district) } \\
\text { - In 2012, seed money } \\
\text { replenished with Del Mar's P2- } \\
\text { million PDAF } \\
\text { - Undertakes activities } \\
\text { throughout the year }\end{array}$ \\
\hline
\end{tabular}




\begin{tabular}{|c|c|c|}
\hline $\begin{array}{l}\text { Media } \\
\text { Advocacy } \\
\text { Group }\end{array}$ & Profile & Highlights \\
\hline $\begin{array}{l}\text { Cebu News } \\
\text { Workers' } \\
\text { Foundation } \\
\text { (CENEWOF) }\end{array}$ & $\begin{array}{l}\text { Organized by Concepcion G. } \\
\text { Briones, president emeritus } \\
\text { of the Association of Cebu } \\
\text { Journalists, and Pachico A. } \\
\text { Seares, editor-in-chief of The } \\
\text { Freeman, in } 1979 \\
\text { - Aims to help the "poor workers } \\
\text { of print media" } \\
\text { - One of the pioneering and still } \\
\text { active media advocacy groups } \\
\text { in Cebu }\end{array}$ & $\begin{array}{l}\text { - Offers trainings, scholarship } \\
\text { and travel, medical and legal } \\
\text { aid, housing, and livelihood } \\
\text { for the "promotion of the } \\
\text { well-being of journalists and } \\
\text { the growth of a free and } \\
\text { responsible press" } \\
\text { - Initiated the campaign to } \\
\text { request local governments } \\
\text { to rename streets after } \\
\text { distinguished local journalists } \\
\text { - Street-renaming project } \\
\text { recognizes print journalists } \\
\text { contributing to Cebu and sets } \\
\text { them up as models for present } \\
\text { colleagues and youths } \\
\text { - Partners with CCPC and CPFWI } \\
\text { in the street-renaming project } \\
\text { - Undertakes activities } \\
\text { throughout the year }\end{array}$ \\
\hline $\begin{array}{l}\text { Cebu News } \\
\text { Workers } \\
\text { Multi- } \\
\text { purpose } \\
\text { Cooperative } \\
\text { (Cebu News } \\
\text { Coop) }\end{array}$ & $\begin{array}{l}\text { - Counts as members Cebu } \\
\text { journalists and their families } \\
\text { - Promotes savings, alternative } \\
\text { livelihood, housing and other } \\
\text { financial assistance to some } 500 \\
\text { members of the press } \\
\text { - P9.157 million, total assets in } \\
2005 \\
\text { - One of the pioneering and still } \\
\text { active media advocacy groups } \\
\text { in Cebu }\end{array}$ & $\begin{array}{l}\text { Undertakes activities } \\
\text { throughout the year }\end{array}$ \\
\hline $\begin{array}{l}\text { Cebu Press } \\
\text { Freedom } \\
\text { Week Inc. } \\
\text { (CPFWI) }\end{array}$ & $\begin{array}{l}\text { - Activated in } 2011 \text { after The } \\
\text { Freeman begged off as lead } \\
\text { convenor for the 17th CPFW } \\
\text { - Lead organizer and franchise } \\
\text { holder of CPFW } \\
\text { - Duly registered corporation } \\
\text { - Board of trustees composed of } \\
\text { Cebu tri-media members }\end{array}$ & $\begin{array}{l}\text { - Publishes in local dailies full and } \\
\text { detailed accounting of CPFW } \\
\text { donations and expenses } \\
\text { - Oversees lineup of official CPFW } \\
\text { activities: "Reaching Out to } \\
\text { News Sources," "Reaching Out to } \\
\text { Future Journalists," and "Coping } \\
\text { with New Media”" }\end{array}$ \\
\hline
\end{tabular}

Sources: Basilan, 2011, p. 14;"Cebu Journalists: A Lot to Thank for," 2006, pp. 6-7; "Cebu Press Freedom Week Through the Years," 2004, p. 55; Lim, 2010, p. 63; Lim, 2013, p. 54; Tabada, 2013, p. 28; Seares, 2008, p. 4; Seares, 2012, p. 15; "Timeline: Cebu Press Freedom Week," 2010, p. 56; "Timeline: Cebu Press Freedom Week through the years," 2011, p. 18 
For the CCPC, the pursuit to put in place press accountability began in 2001 when the editors-in-chief of the three English-language dailies in Cebu-Eileen Mangubat of the Cebu Daily News, Pachico A. Seares of Sun.Star Cebu, and Noel Pangilinan of The Freeman-met in Manila with Marvin Tort, PPC executive director ("Cebu Citizens-Press Council," n.d.). They discussed setting up a press council in Cebu. In Cebu, Juan L. Mercado, then a columnist for Sun.Star Cebu, Cebu Daily News, and Philippine Daily Inquirer, joined Mangubat, Seares, and Pangilinan in laying the groundwork for the organization. Mercado is the PPI's founding director (Cebu Citizens Press Council, n.d.).The group consulted other media advocacy stakeholders, including Melinda Quintos de Jesus, CMFR executive director. The organization was interested to set up press councils in Cebu, Palawan, and Baguio.

A self-regulatory body introduced in Sweden in 1940, the press council has been accepted and replicated in the United Kingdom and other countries (Miranda, 2002a). In the Philippines, the experiences of the PPIinitiated PPC surfaced many problems, such as the "reluctance of aggrieved persons to file complaints" (p. 36). and "the public's lack of information on the existence and role of the council" (p. 36). Another problem was the difficulty in terms of resources and time for a Metro Manila-based press council to receive and act on complaints from communities outside of Manila (p. 36). During the PPI's 6th National Press Forum, Marvin Tort, news editor of Business World and PPC chairperson, declared that the press council "doesn't work" (p. 36).

Believing in the citizens' press council as a self-regulating mechanism for media accountability, the CMFR partnered with local partners in Cebu, Baguio, and Palawan to initiate regional press councils. The CMFR had preliminary meetings with potential partners in August 2001, after which the plan was made to establish press councils in Cebu, Baguio, and Mindanao. Due to the crisis in Mindanao, Palawan became the third site (Miranda, 2002a, p. 37).

During a national roundtable meeting on the "Corruption in Media: A Multi- Sectoral Perspective" held on October 8-10, 1999, twenty-eight leaders of the community press in the country formalized plans to organize regional press councils, with the participation of non-media sectors, as a "new framework ... to help instill greater ethical compliance and professionalism in the performance of the free press in the country" (Miranda, 2002a, p. 37). Mangubat (in Miranda, 2002a) told the Philippine Journalism Review that the inclusion of non-journalists in the councils would "disprove the public perception that a press council is an 'old boys' club' formed by journalists to protect their own" and prove the "industry's willingness to listen and (its) sincerity in seeking reforms (in the media)" (p. 37). 
The CCPC had a soft launch on May 5, 2002, with a formal launch in September 2002 to coincide with Cebu Press Freedom Week. It was followed by the launching of two other CMFR-assisted CPCs: Baguio Citizens Press Council (BCPC) on May 30, 2002 and Palawan Community Media Council (PCMC) on June 8, 2002 (Elumbre \& Tuazon, 2005; Macale, 2003).

On September 16, 2002, prospective members of the CCPC met at the Laguna Garden Café in Cebu City ("Cebu Citizens-Press Council," n.d.). Seares presented to the assembly a proposal for basic rules, culled from foreign models, local experience, and local consultations. However, due to the "individual papers' other pressing concerns," the CCPC went into "hibernation" for the next three years (Cebu Citizens Press Council or CCPC, n.d.). Aside from these "internal concerns" of the member newspapers, the CCPC needed an executive director, office space, and budget. Other plans needing implementation were for an information drive by the membernewspapers, the finalization of the by-laws and rules, and participation of more citizens as CCPC members (Elumbre \& Tuazon, 2005).

In February 2003, Cebu Daily News publisher Eileen Mangubat informed the Philippine Journalism Review that the Cebu Newspaper Workers Foundation (CENEWOF) and the Marcelo Fernan Press Center in Lahug, Cebu committed a room for CCPC use (Macale, 2003; Miranda, 2002b). The office was to serve as a "neutral body, complete with an executive director and staff so that media organizations will not perceive it as biased" (Macale, 2003, p. 19). Seares recalled:

Things were ready by the second year but the unofficial lead convenor seemed to have dropped the idea until that month towards the September 2005 Press Week when our group met and I volunteered that Sun.Star (Cebu) take the lead as (the) CCPC convenor because no one else would do it. (P. Seares, personal communication, November 18, 2014).

\section{Seares and Sun.Star Cebu took over from Mangubat in reactivating the CCPC.}

According to Amado "Jake" Macasaet (as quoted in Bengco, 2011), publisher of Malaya and PPI chairman-emeritus, the CCPC is the "most active" (para. 75) of the regional press councils. Macasaet made this comment to former Malaya reporter Regina Bengco (2011), who undertook a research project on the PPC for the 2011 Asia Journalism Fellowship held in Singapore on Feb. 7 to April 29, 2011. Founded in 2001 but reactivated in 2005, the CCPC represents Cebu's print media, the local chapter of 
$\mathrm{KBP}$, and the private sector such as businesses, civic organizations, and the academe.

The CCPC "provides a forum for news subjects to air their grievances so that the incidence of lawsuits and violence against journalists may be reduced" (Lim, 2010, p. 63). The Council also seeks to promote among journalists a culture of professionalism and ethical conduct, which encourages journalists to police their ranks. Lastly, the CCPC "helps the public understand the work of media" (p. 63).

There are five dailies in Cebu: The Freeman and Banat News, published by the Star Group of Publications; Sun.Star Cebu and Sun.Star Superbalita Cebu, published by the Sun.Star Publishing; and Cebu Daily News, published by the Inquirer Publications. The Freeman, Sun.Star Cebu, and Cebu Daily News are in English; Banat News and Sun.Star Superbalita Cebu are in Cebuano. CCPC's public members are Dr. Pureza Oñate, who is also CCPC president and Cebu Newspaper Workers Foundation (CENEWOF) chairperson; Sabino Dapat, CCPC vice president and president of Mitsubishi Motors Cebu Corporation; Fr. Aloysius Cartagenas, CCPC treasurer and former rector of Seminario Mayor de San Carlos; Atty. Jonathan Capanas, CCPC secretary and dean of the College of Law of the University of San JoseRecoletos; Jose Rafael Ferreros, former senior assistant governor Rotary International district 3860; and Mario King, president and chief executive officer of Nito's International Ventures (CCPC, n.d.).

CCPC semi-media members are Ma. Theresa Q. Tabada, instructor of Mass Communications at UP Cebu; and Mia E. Mateo, mass communications coordinator of St. Theresa's College Cebu. Academics straddle the mediae.g., Tabada writes a weekly column and editorial for Sun.Star Cebu-and the public, and semi-media members provide the "swing vote" or "voice of moderation" (CCPC, n.d.; Seares, personal communication, July 3, 2015). CCPC media members are Jun Tagalog of dyLA-AM who was the 2014 chairman of the KBP, Cebu Chapter; Manny Galicia of Smooth FM, 2014 KBP-Ceby executive vice-chairman; Quennie Bronce, editor-in-chief of The Freeman and Banat News; Isolde D. Amante, editor-in-chief of Sun.Star Cebu; Eileen G. Mangubat, publisher of Cebu Daily News; and Michelle P. So, editor-in-chief of Sun.Star Superbalita Cebu. Sun.Star Cebu public and standards editor Atty. Pachico A. Seares is the CCPC executive director, and Sun.Star Cebu managing director for special pages and features Cherry Ann T. Lim, the deputy director. On-leave from the CCPC are Cartagenas and Tabada (CCPC, n.d.).

The Council's Rules of Procedure and Code of Practice were adopted by the editors-in-chief of the five Cebu dailies and ratified by the CCPC body composed of fifteen public and media members during the quarterly 
meeting at Café Georg in Cebu City on February 3, 2006 ("Cebu Citizens Press-Council," n.d.). To help enforce the code, CCPC calls on publishers, media owners, editors, and news directors to promote in their respective newsrooms the basics of fairness and accuracy. CCPC also recognizes that every news organization has its own code of ethics and standards by which it can also be held accountable.

As posted on the official CCPC website, CCPC's code of practice highlights the practices of accuracy and fairness as standard and ethical ("Cebu Citizens-Press Council," n.d.). To uphold the right of reply, CCPC urges every media outlet to allow those mentioned or affected by the news to air their side; and that the right to reply is governed by space availability and other media considerations while upholding the spirit of fairness. For accuracy, the CCPC highlights four considerations: media outlets must strive to publish material that is accurate, not misleading or distorted; information must include attribution; correction of errors must be prompt and prominent; and clear distinction must be made between news and opinion.

The CCPC mediates on complaints from citizens who have sought corrections in media reports but were dissatisfied by the response of the concerned newspaper or newspapers. Responding to citizens with media grievances concerning accuracy and fairness or right of reply is the reactive mechanism of the CCPC advocacies. During the September 21, 2006 CCPC quarterly en banc meeting, it was reported that the CCPC had been registered with the Securities and Exchange Commission (SEC) as a nonstock, nonprofit organization (Lim, 2010).

A year after its reactivation, the CCPC put up a website: www. cebucitizenspresscouncil.org. Aside from containing posts on key information about the organization, the website has become a new media tool for community engagement. Seares (as cited in Elumbre, 2006a) said that the CCPC is not just a mechanism giving recourse to offended parties and acting on complaints about local media but a "regular forum whose voice ... will help decisions affecting media, locally or otherwise" (p. 9). Mercado (as cited in Elumbre, 2006b) observed that the CCPC acts "more (as) a channel of dialogue between the community and the press so that better standards are adopted" (p. 16).

Aside from its reactive advocacy of responding to citizens' complaints about newspaper accuracy and fairness, the CCPC initiates two proactive advocacies for media self-regulation and professionalism among individual journalists, newspaper institutions, and media associations in Cebu, as well as media literacy for non-journalists. Unlike in the complaints adjudication process that entails the CCPC's reacting or responding to complainants by 
forwarding their grievance to the concerned newspaper, the two advocacies are CCPC-driven initiatives, with the Council deciding which issues concerning media self-regulation and media literacy are to be the foci for the public consultations, journalistic guidelines, media self-regulation, and media literacy campaigns it conducts with other Cebu stakeholders.

CCPC proactively pursues advocacies in two ways: First, it acts as a "forum for dialogues with sectors of the community covered by mediaelective officials, police, priests, NGOs (non-government organizations), prosecutors," according to the CCPC executive director, lawyer Pachico A. Seares (personal communication, November 13, 2012). The public and standards editor of Sun.Star Cebu and Sun.Star Superbalita also said in his email to this researcher that from these public discussions, the CCPC "adopted guidelines for journalists and their public" (personal communication, November 13, 2012) As stated earlier, the CCPC's code of practice states that the CCPC appeals to publishers, media owners, editors, and news directors to promote and enforce in their respective newsrooms these journalistic guidelines. The CCPC also recognizes that every news organization has its own code of ethics and standards, which reinforces these journalistic guidelines (CCPC, n.d.).

In the second focus of its proactive advocacies, the CCPC creates campaigns to "stir awareness of media issues and promote media literacy, not just among news sources but also of media consumers (P. Seares, personal communication, November 13, 2012). Media literacy is the essential complement of the CCPC media self-regulation advocacy. "The public must be media literate if it is not to be manipulated by the various interests, biases and failings that drive the media even in-some argue specially inregimes of media freedom" (Teodoro, 2002, p. 134). In 2002, the CMFR recommended to the regional CPCs it helped initiate in Cebu, Baguio, and Palawan media literacy to be incorporated in their advocacies. In these regional CPCs, civil society leaders compose the membership, along with journalists. As part of the CCPC's institutionalization of its partnerships to sustain the gains of media literacy, CCPC executive director Seares and deputy director Lim were invited on August 9, 2014 by the PPI to share their CCPC experience with Bacolod stakeholders: the press, academe, religious, business and labor leaders. With the support of Coca-Cola Femsa, the PPI is conducting a series of roundtable discussions on the press council as part of its advocacies marking its 50th anniversary. Davao and General Santos will also be the venues of PPI roundtable discussions on the press council. A national association of newspapers, the PPI, represented by chairman and president Jesus Dureza, announced the intent to help promote the creation of press councils as a public redress mechanism during the 18th National Press Forum (Lim, 2014). 
The CCPC follows the pattern of other media advocacy groups in Cebu and other places in the country. Formed initially to protect press freedom from external adversaries, Cebu media associations learned to turn the lens of scrutiny inward, particularly when the issue of "envelopmental journalism" and media corruption was raised in 1992 by two politicians (Basilan, 2011, p. 13). The issue of media corruption continues to hound Cebu media up to the writing of this study, as perceived by key informants from the media and civil society.

The media advocacy groups in Cebu present the second tier of media self-regulation. These groups were initially formed among journalists with a shared sense of press freedom and media responsibility (Tabada, 2015). By consolidating and organizing as an industry, the newsrooms exercised more collective clout against adversaries and threats to its freedoms. By focusing on self-regulation within the industry, media advocacy groups learned to balance media competition and the tendency of media organizations to prioritize their individual corporate interests and powers. Consistent with Bagdikian's (2004) identification of remedies countering the abuse of media powers, Cebu's media advocacy groups perform the function of Bagdikian's media reform groups: they reassert media's social responsibility and stake in the public interest, and empower citizens and netizens as media watchdogs, primarily through media literacy and stakeholdership in media self-regulation.

Table 3 shows the milestones of Cebu journalists' activism, the causes, and the participants:

Table 3: Milestones of Cebu Journalists' Activism (1984-2014).

\begin{tabular}{|c|c|c|c|}
\hline Milestones & Date & Cause & Participants \\
\hline $\begin{array}{l}\text { Organization and } \\
\text { conduct of the } \\
\text { first Cebu Press } \\
\text { Freedom Week } \\
\text { (CPFW) }\end{array}$ & $\begin{array}{l}\text { Sept. 9-15, } \\
1984\end{array}$ & $\begin{array}{l}\text { - "Cebu media started to } \\
\text { work in groups after the } \\
\text { lifting of martial law" } \\
\text { - ACJ president Pachico } \\
\text { A. Seares, former editor- } \\
\text { in-chief of Sun.Star Cebu } \\
\text { "pushed media groups.. } \\
\text {.to celebrate and watch } \\
\text { over freedom of expression } \\
\text { in the country." }\end{array}$ & $\begin{array}{l}\text { - Association of Cebu } \\
\text { Journalists (ACJ) } \\
\text { - Cebu Newspaper Workers' } \\
\text { Foundation (CENEWOF), } \\
\text { now Cebu News Workers' } \\
\text { Foundation } \\
\text { - Cebu News } \\
\text { Correspondents Club } \\
\text { - Sun.Star Daily, now Sun.Star } \\
\text { Cebu }\end{array}$ \\
\hline
\end{tabular}




\begin{tabular}{|c|c|c|c|}
\hline Milestones & Date & Cause & Participants \\
\hline $\begin{array}{l}\text { Formation of } \\
\text { Council of Cebu } \\
\text { Media Leaders } \\
\text { (CCML) }\end{array}$ & $\begin{array}{l}\text { Sept. 10, } \\
1988\end{array}$ & $\begin{array}{l}\text { - Upgrade journalism } \\
\text { practices } \\
\text { - Encourage journalists to } \\
\text { police their ranks } \\
\text { - Signed a manifesto of } \\
\text { solidarity }\end{array}$ & $\begin{array}{l}\text { - Convenor: Pachico A. } \\
\text { Seares, Sun.Star Daily } \\
\text { editor-in-chief } \\
\text { - Various media } \\
\text { organizations in Cebu }\end{array}$ \\
\hline $\begin{array}{l}\text { Celebration of } \\
\text { CPFW }\end{array}$ & 1988 & $\begin{array}{l}\text { - Continue the causes of } \\
\text { the first CPFW: industry } \\
\text { solidarity and press } \\
\text { freedom }\end{array}$ & $\begin{array}{l}\text { - CCML, chaired by Seares } \\
\text { and involving heads of } 11 \\
\text { media clubs in Cebu }\end{array}$ \\
\hline $\begin{array}{l}\text { CCML resolution, } \\
\text { newspaper } \\
\text { editorials, } \\
\text { and radio } \\
\text { commentaries } \\
\text { condemning } \\
\text { "blatant attempt } \\
\text { to suppress } \\
\text { legitimate news } \\
\text { coverage" of } \\
\text { dyMF-AM radio } \\
\text { commentator } \\
\text { Bobby Nalzaro }\end{array}$ & Nov.1990 & $\begin{array}{l}\text { - Nov. 19, } 1990 \text { mauling } \\
\text { and coercion with the use } \\
\text { of firearms of Nalzaro by } \\
\text { bodyguards of Mandaue } \\
\text { businessman Ernesto } \\
\text { Ouano, Sr. and son Nene. } \\
\text { Nalzaro criticized the } \\
\text { businessman's excessive } \\
\text { barge fares for Mactan- } \\
\text { Mandaue. }\end{array}$ & $\begin{array}{l}\text { - CCML } \\
\text { - Cebu editors } \\
\text { - Cebu radio commentators }\end{array}$ \\
\hline $\begin{array}{l}\text { CCML resolution, } \\
\text { print editorials, } \\
\text { and radio } \\
\text { commentaries } \\
\text { condemning } \\
\text { harassment and } \\
\text { death threats } \\
\text { made on Sun.Star } \\
\text { Daily columnist } \\
\text { Wilfredo A. Veloso } \\
\text { and his family }\end{array}$ & Nov.1991 & $\begin{array}{l}\text { - Nov. 5, } 1991 \text { assault of } \\
\text { Veloso by Narcotics } \\
\text { Command } 7 \text { chief Esa } \\
\text { Hasan and three officers } \\
\text { at the Sun.Star Daily } \\
\text { Central Newsroom. Veloso } \\
\text { criticized Narcom's anti- } \\
\text { drug campaign. }\end{array}$ & $\begin{array}{l}\text { - CCML } \\
\text { - Cebu editors } \\
\text { - Cebu radio commentators }\end{array}$ \\
\hline
\end{tabular}




\begin{tabular}{|c|c|c|c|}
\hline Milestones & Date & Cause & Participants \\
\hline $\begin{array}{l}\text { CCML resolution } \\
\text { criticizing } \\
\text { politicians' } \\
\text { "blanket charges" } \\
\text { to "cow their } \\
\text { critics into } \\
\text { submission" and } \\
\text { doubting if a } \\
\text { House inquiry on } \\
\text { media corruption } \\
\text { will be "useful" }\end{array}$ & $\begin{array}{l}\text { Nov. 28, } \\
1992\end{array}$ & $\begin{array}{l}\text { - Two politicians charged } \\
\text { local media with } \\
\text { corruption. }\end{array}$ & - CCML \\
\hline $\begin{array}{l}\text { CCML resolution } \\
\text { opposing } \\
\text { "congressional } \\
\text { interference" in } \\
\text { media }\end{array}$ & Dec. 3, 1992 & $\begin{array}{l}\text { - Two politicians charged } \\
\text { local media with } \\
\text { corruption }\end{array}$ & $\begin{array}{l}\text { - CCML, representing Press } \\
\text { Photographers of the } \\
\text { Philippines, Cebu chapter, } \\
\text { Sukna, Cebu Tri-Media } \\
\text { Association, and Cebu } \\
\text { Association of Media } \\
\text { Practitioners }\end{array}$ \\
\hline $\begin{array}{l}\text { Celebration of } \\
\text { CPFW }\end{array}$ & $\begin{array}{l}\text { Sept. 18-24, } \\
1994\end{array}$ & $\begin{array}{l}\text { "Remind the public and } \\
\text { the press itself that the } \\
\text { precious freedom it now } \\
\text { enjoys must be protected } \\
\text { from any and all threats" }\end{array}$ & - CCML \\
\hline $\begin{array}{l}\text { Cancellation of } \\
\text { CPFW, observed } \\
\text { annually since } \\
1994\end{array}$ & 1996 & $\begin{array}{l}\text { - CCML "stung by... criticism } \\
\text { about legitimacy and } \\
\text { motives." } \\
\text { - In 1997, CCML found non- } \\
\text { media groups pretended } \\
\text { to be media practitioners } \\
\text { and solicited funds for } \\
\text { Cebu Press Freedom Week. }\end{array}$ & $\begin{array}{l}\text { - CCML } \\
\text { - Cebu newspapers }\end{array}$ \\
\hline $\begin{array}{l}\text { Reorganization of } \\
\text { CPFW }\end{array}$ & 1997 & $\begin{array}{l}\text { Working group composed } \\
\text { of members of Cebu } \\
\text { newspapers and news- } \\
\text { and-public-affairs radio } \\
\text { and television stations } \\
\text { took over to prevent } \\
\text { "dubious" media groups } \\
\text { from exploiting the CPFW. }\end{array}$ & - Cebu working media \\
\hline
\end{tabular}




\begin{tabular}{|c|c|c|c|}
\hline Milestones & Date & Cause & Participants \\
\hline $\begin{array}{l}\text { Celebration of } \\
\text { CPFW on the } \\
\text { week of the } \\
\text { anniversary of } \\
\text { martial law's } \\
\text { declaration }\end{array}$ & 1998 & $\begin{array}{l}\text { - Cebu City Council and } \\
\text { Cebu Provincial Board } \\
\text { passed resolutions } \\
\text { declaring the "week in } \\
\text { September that includes } \\
\text { Sept. } 21 \text { as Cebu Press } \\
\text { Freedom Week every year." }\end{array}$ & $\begin{array}{l}\text { - Cebu working media } \\
\text { - Public }\end{array}$ \\
\hline $\begin{array}{l}\text { Institutionaliza- } \\
\text { tion of CPFW }\end{array}$ & 1999 & $\begin{array}{l}\text { - Annual organization of } \\
\text { CPFW to be initiated by } \\
\text { each of the three Cebu } \\
\text { English dailies-The } \\
\text { Freeman, Cebu Daily News, } \\
\text { and Sun.Star Cebu-as } \\
\text { lead convenor }\end{array}$ & $\begin{array}{l}\text { - Convenors' group } \\
\text { composed of leaders from } \\
\text { working media } \\
\text { - Cebu working media } \\
\text { - Public }\end{array}$ \\
\hline $\begin{array}{l}\text { Takeover of Cebu } \\
\text { Press Freedom } \\
\text { Week Inc (CPFWI) } \\
\text { in organizing } \\
\text { CPFW }\end{array}$ & 2011 & $\begin{array}{l}\text { - After The Freeman begged } \\
\text { off as lead convenor, } \\
\text { CPFWI activated as lead } \\
\text { organizer and franchise } \\
\text { holder. } \\
\text { - CPFWI is a duly registered } \\
\text { corporation representing } \\
\text { the print media-i.e., three } \\
\text { Cebu English dailies and } \\
\text { two Bisaya dailies-and } \\
18 \text { news and public affairs } \\
\text { broadcast stations. }\end{array}$ & $\begin{array}{l}\text { - CPFWI } \\
\text { - Cebu newspapers } \\
\text { - Cebu working media } \\
\text { - Public }\end{array}$ \\
\hline $\begin{array}{l}\text { 22nd celebration } \\
\text { of CPFW }\end{array}$ & $\begin{array}{l}\text { Sept. 20-27, } \\
2014\end{array}$ & $\begin{array}{l}\text { - CPFWI oversees the } \\
\text { lineup of official activities } \\
\text { falling under three major } \\
\text { categories: "Reaching } \\
\text { Out to News Sources," } \\
\text { "Reaching Out to Future } \\
\text { Journalists," and "Coping } \\
\text { with New Media." } \\
\text { - CPFWI publishes in Cebu } \\
\text { dailies a full and detailed } \\
\text { accounting of donations } \\
\text { and expenses incurred for } \\
\text { the celebrations. }\end{array}$ & $\begin{array}{l}\text { - CPFWI } \\
\text { - Cebu newspapers } \\
\text { - Cebu working media } \\
\text { - Public }\end{array}$ \\
\hline
\end{tabular}

Sources: B. Nalzaro, personal communication, November 9, 2014; “Cebu Press Freedom Week Through the Years," 2004, p. 54-55;"Cebu Press Freedom Week," 2013, p. 22; Cuizon, 2014, p. 26-27; Basilan, 2011, p. 14; “Timeline: Cebu Press Freedom Week through the years," 2011, p. 18 


\section{CCPC's Reactive Mechanism in Complaint Adjudication}

When CCPC was launched in Cebu in 2001 and then revitalized in 2005, it fit in with Cebu's historical, institutional, and cultural framework that is conducive to media self-regulation. Like the print newsrooms and other media advocacy groups, the CCPC sustains and institutionalizes the culture of media self-regulation in Cebu. It also fills a gap because the CCPC is the first and only media advocacy group in Cebu that involves public members and partners the media and the public to share the stake for media selfregulation (Tabada, 2015). The annual Cebu Press Freedom Week (CPFW) already established a local tradition of involving citizens in commemorating freedom of expression. Although the CPFW involves many sectors, it is not an entity (CPFWI was formed in 2011) like CCPC, which is active throughout the year and holds regular quarterly meetings.

The CCPC pursues three major advocacies to promote media selfregulation and media literacy: the reactive advocacy for complaint adjudication, the proactive advocacy for media self-regulation, and the proactive advocacy for media literacy. Although the CСPC varies in its focus during its campaigns, the three advocacies are mutually reinforcing (Tabada, 2015).

Media literacy's opportunities for strengthening the participation of citizens and netizens reinforce media self-regulation and the protection of freedom of expression. This is important to highlight since some regional citizens press councils (CPCs), supported by the Center for Media Freedom and Responsibility (CMFR), focus on either media self-regulation or media literacy but rarely on the interplay between these two advocacies. The Dumaguete Press Council (DPC), founded on May 24, 2005, is the only press council in the country that does not have non-journalist members because of the members' apprehension that the former will try to influence any DPC investigation of issues involving their interests (Elumbre, 2006b). The Baguio Citizens Press Council (BCPC) focuses solely on media literacy for mass communication students.

Through the complaint adjudication advocacy, the CCPC mediates between citizens with a complaint and the concerned Cebu dailies. In its public service announcements published in member newspapers and posted on the CCPC website, the CCPC encourages the public to bring their complaint concerning accuracy and fairness to the attention of local dailies ("Cebu Citizens-Press Council," n.d.). If the citizen is not satisfied with the newspaper's response, the CСPC offers itself as the alternative venue for mediating between the complainant and the paper.

The CCPC founders, like the PPC founding fathers, chose to focus first on guaranteeing the right of reply to every news subject ("Cebu 
Citizens-Press Council," n.d.). This was not only viewed as "fundamentally fair" to voluntarily grant news space to those who had a complaint about the press making a mistake in its report or analysis, not getting the side of the complainant in a controversy, misinterpreting or misrepresenting information, or other lapses in news coverage. By granting right of reply, a complainant's access to the media to air and seek correction and redress for a grievance acted also as an ounce of prevention that is worth a cure. By taking publicly their lesson in accountability and responsibility, journalists "increased their credibility" and "decreased their susceptibility to court action" (Mariano, 2002, p. 67). Granting the right of reply to news sources also argued against the need to legislate right of reply and "might help temper the resort to violence in Philippine society" (De Jesus \& Khan, 2005, p. 15) in light of the high number of media killings in the country.

While the public is given access to an alternate grievance mechanism, public response to the CCPC's reactive advocacy has not been high during the eight years (2005-2013) covered by this study. Like the Philippine Press Council (PPC) and other regional CPCs like the Palawan Community Media Council (PCMC), the CCPC faces a problem of receiving few complaints. Of these received complaints, few are confined to the issues of accuracy and fairness, which are the only complaints addressed by the CCPC.

As with the PPC and PCMC, the CCPC can treat the scarcity of valid complaints as a problem to be solved through a more aggressive and continuing campaign of informing the public about the CCPC's existence and its service as an alternative grievance forum. The CCPC must also consider implementing a follow-up system to determine how the complaint had been handled by the newspaper. Although it currently treats each complaint as confidential, the council should also consider documenting and disseminating updates about its complaint adjudication process. By doing so, it informs its members and the public about the effectiveness of the complaint adjudication mechanism and encourages other citizens to raise their grievance. Important for promoting media transparency and answerability, as well as media literacy, the strategy will counter the perception that the CCPC protects the interests of local media.

Another significant finding is that the study underscored the link between complaint adjudication and media literacy. To increase the incidence of citizens monitoring and complaining against newspaper lapses and excesses, the CCPC must improve the citizens' media literacy, including the netizens' in Cebu. Before citizens and netizens can critically and constructively engage the media, they need to have basic knowledge about the latter, their work, the values and standards influencing media work, media's relations with 
other institutions, digital media, and the public's rights vis-à-vis the media. Including digital journalists and netizens in the CCPC as media and public members gives them a venue to participate in Cebu discourse and initiatives for media self-regulation and media literacy, which has yet to fully respond to the challenges of new media and online engagement. Both Ben Bagdikian (2004) and Manuel Castells (2010) underscore the crucial role of citizens, civil society, alternative media, youths, and netizens with their facility for and access to instruments of digital media for mobilizing nonviolent protest and resistance opposing the abuse of power by media and other elites.

Table 4 summarizes the trends observed in the CCPC's eight-year adjudication of citizens' complaints against newspapers, as well as stakeholders' comments and suggestions for the improvement of the council's complaint adjudication process.

Table 4. Trends in the CCPC's Complaint Adjudication Advocacy

\begin{tabular}{|l|l|}
\hline \multicolumn{1}{|c|}{ Trends } & \multicolumn{1}{|c|}{ Stakeholders' Feedback } \\
\hline $\begin{array}{l}\text { 1. The CCPC's reactive } \\
\text { advocacy encourages media to } \\
\text { voluntarily grant right of reply to } \\
\text { complainants. }\end{array}$ & $\begin{array}{l}\text { Comment: Cebu newspapers already practiced self-regulation } \\
\text { before the CCPC operated (source: newspaper editor). } \\
\text { Comment: The CCPC's advocacy strengthens newsroom integrity } \\
\text { by bridging any gap between the media and the public (source: } \\
\text { newspaper editor). } \\
\text { Comment: The CCPC presents another venue to ventilate grievance } \\
\text { if a complainant is dissatisfied by a newspaper's response (source: } \\
\text { newspaper editor). }\end{array}$ \\
\hline $\begin{array}{l}\text { 2. The CCPC received 15 } \\
\text { complaints against newspapers' } \\
\text { lapses during the eight-year } \\
\text { period of study. }\end{array}$ & $\begin{array}{l}\text { Comment: There are few complaints made to the CCPC (source: } \\
\text { CCPC secretariat). } \\
\text { Comment: } \text { No complaint was coursed to the CCPC secretariat } \\
\text { through a link in the CCPC website (source: CCPC secretariat). } \\
\text { Suggestion: The CCPC strengthens its campaign to inform citizens } \\
\text { of the CCPC website link for sending complaints concerning } \\
\text { newspapers or any feedback (source: newspaper editors). } \\
\text { Suggestion: } \text { The CCPC conducts a media literacy to educate citizens } \\
\text { outside urban centers so they can act as media watchdogs (source: } \\
\text { media advocacy group). }\end{array}$ \\
\hline $\begin{array}{l}\text { 3. Only eight of the 15 } \\
\text { complaints were related to } \\
\text { accuracy and fairness or right } \\
\text { of reply. }\end{array}$ & $\begin{array}{l}\text { Comment: Of these few complaints, few touch on accuracy and } \\
\text { fairness or right of reply, which are the only complaints addressed } \\
\text { by the CCPC (source: CCPC secretariat). } \\
\text { Comment: Only one, a few or no complaint was or were forwarded } \\
\text { to the newspapers by the CCPC (source: newspaper editors). } \\
\text { Suggestion: The CCPC conducts a media literacy to educate citizens } \\
\text { outside urban centers so they can act as media watchdogs (source: } \\
\text { media advocacy group). }\end{array}$ \\
\hline
\end{tabular}




\begin{tabular}{|l|l|}
\hline \multicolumn{1}{|c|}{ Trends } & \multicolumn{1}{c|}{ Stakeholders' Feedback } \\
\hline $\begin{array}{l}\text { 4. After the CCPC secretariat } \\
\text { forwards the complaint to the } \\
\text { concerned newspaper, it does } \\
\text { not make a follow-up with the } \\
\text { newspaper on any action taken. }\end{array}$ & $\begin{array}{l}\text { Comment: After the complaint is received by the newspaper, } \\
\text { editors address the complaint according to its internal mechanisms } \\
\text { of answerability (source: CCPC secretariat and newspaper editors). } \\
\text { Comment: No complainant has complained to the CCPC that his or } \\
\text { her complaint was not addressed (source: CCPC secretariat). } \\
\text { Comment: Indirect feedback came when the CCPC read an article } \\
\text { the newspaper published on the concern of the complaint, or } \\
\text { the complainant thanked the CCPC for its help (source: CCPC } \\
\text { secretariat and newspaper editor). } \\
\text { Suggestion: There are "many ways" to improve the CCPC process, } \\
\text { which can be refined by CCPC officials (source: newspaper editor). } \\
\text { Suggestion: The CCPC gives a regular update to editors on the } \\
\text { status of the complaints it received and forwarded (source: } \\
\text { newspaper editor). }\end{array}$ \\
\hline
\end{tabular}

\section{CCPC's Proactive Mechanism in MSR}

The CCPC's proactive advocacy of promoting media self-regulation builds on the community of journalists that, institutionally and culturally, supports media self-regulation. As a media accountability mechanism, the CCPC mobilizes peer orientation to put pressure on individual journalists to follow the norms of journalistic ethics and standards. The Council also acts as a channel of the public sphere in bringing together journalists and various sectors of the public, such as human rights advocates, law enforcers, the church, and women and child advocates, to discuss and come up with a consensus on how to resolve areas of conflict in covering these sectors. The resulting guidelines were disseminated to guide journalists and citizens. Indirectly, the CCPC educates the public about the standards by which it can hold the media accountable in covering sectors, especially the vulnerable and marginalized.

Public campaigns through CCPC-filed position papers, statements, and resolutions also inform and educate the public, including journalists, and enable them to contribute to the discourse. This proactive advocacy mobilizes media power to influence the passage of laws that promote freedom of expression and the public's right to know. The media selfregulation advocacies perceived by key informants as having the most consequence for Cebu focused on the defense of press freedom and freedom of expression (i.e., filing of resolutions in local governments, local legislatures, Congress, and the Senate supporting the amendment of the Sotto Law (also known as the Press Freedom Law, Republic Act No. 53 that shields journalists from revealing the identities of confidential sources) and limiting the venue of libel; opposing right of reply bills; supporting some elements in the decriminalization of libel; reconsidering bills that promote journalists' welfare; seeking passage of the Freedom of Information (FOI) 
Act; objecting to The Cybercrime Prevention Act of 2012; opposing the Magna Carta for Journalists; reiterating support for media bills House Bill 26 (also known as the proposed Freedom of Information Act of 2013), House Bill 362 (extending the coverage of the Sotto Law to broadcast and digital journalists so they cannot be compelled to reveal confidential sources if not involving the security of the state), and House Bill 363 (seeking to limit the venue of libel and similar complaints to the principal office of the press); and urging journalists to reject subpoenas and summonses from local legislatures to explain news or opinion, among others), the balance between press freedom and media responsibility, and the promotion of social values (i.e., the common search for truth, presumption of innocence, repudiation of "trial by publicity," and protection of the rights of the most vulnerable in the power equation).

Some CCPC media self-regulation advocacies need strengthening or focusing. Some key informants want the CCPC to have the power to enforce sanctions against journalistic malpractice such as corruption and yellow journalism. However, the experiences of PPC and KBP in disciplining and passing penalties are fraught with difficulties such as lack of resources to conduct investigations and impose sanctions, and the perception of the penalty's failure to match the severity of the violation, as cited by the key informants of the study (Tabada, 2015). With fewer resources than the PPC and the KBP, the CCPC should focus on improving media accountability through peer orientation in the short term and media literacy in the long term.

Key informants also said the CCPC needs to follow up on the adoption by Cebu journalists of recommendations to improve local media coverage of elections, particularly in contributing to voters' education (Tabada, 2015). These recommendations were generated by the CCPC-CMFR- academe content analyses of Cebu media coverage of the elections in 2007 and 2010. Although the guidelines were disseminated to Cebu newspapers, local media's use of these guidelines can be reinforced through continuing CCPC campaigns, in partnership with media advocacy groups and other civil society groups. The CCPC advocacy of improving media electoral coverage and enhancing voters' literacy is important for revitalizing what Bagdikian (2004) calls the crucial role of newspapers in a democracy: providing accurate and critical information to inform and guide citizens' decisionmaking, especially in casting their vote and electing public leaders. While key informants recommended that the CCPC include other non-addressed issues such as stealth marketing in its proactive campaigns for the continuing education of local journalists, much of the suggestions emphasized the role of the CCPC in serving as a channel for the public sphere and a source 
for empowering alternative and marginalized sectors like the grassroots and community media to serve as counterpower in Cebu's network society (Tabada, 2015). Such suggestions focus on the CCPC entering into or sustaining partnerships with the academe and media advocacy groups, as well as opening membership and participation in the council to digital stakeholders, i.e., new journalists, online communities, netizens, youths, and aspiring journalists.

Finally, many key informants recommended that the CCPC conduct regular internal review of its membership, accomplishments, and plans to improve its function (Tabada, 2015). By practicing also self- regulation within its ranks, the CCPC demonstrates its individual members' resolve and the collective will to counter the tendency to become an old boys' club. The Council should also lead Cebu journalists in reviewing alliances with political and business partners in its advocacies to avoid arrangements that involve conflicts of interest and compromise its independence and integrity. Among the suggestions of key informants to invigorate the CCPC is an expansion of membership to include the youth, new media journalists, bloggers, and marginalized sectors to counter conflicts of interest arising from a membership composition that has not widely varied and that represents primarily the media, business, the academe, and the Roman Catholic Church.

But as with the public's participation in complaint adjudication, a more active participation of citizens and netizens in discussing issues concerning media self-regulation requires the CCPC to improve its media literacy advocacy and engagement with other stakeholders, particularly the grassroots, digital journalists, and netizens. Digital literacy and digital engagement are recommended strategies that will promote CCPC's reactive and proactive advocacies.

Table 5 encapsulates CCPC's proactive advocacies on media selfregulation that key informants viewed as needing more strengthening or focusing.

Table 5. CCPC Media Self-regulation Advocacies Needing Strengthening or Focusing. 


\begin{tabular}{|c|c|}
\hline $\begin{array}{c}\text { Media Self-regulation Issues Taken Up in CCPC } \\
\text { Proactive Advocacies }\end{array}$ & $\begin{array}{l}\text { Stakeholders' Recommendations to Improve } \\
\text { CCPC Proactive Advocacies }\end{array}$ \\
\hline 1. Discipline of erring journalists & $\begin{array}{l}\text { - Give power to CCPC to censure Cebu journalist } \\
\text { for malpractice, like KBP. } \\
\text { - Name and expose corrupt journalists. } \\
\text { - Distinguish between legitimate and illegitimate } \\
\text { journalists. } \\
\text { - Publicly disclose any conflict of interest (for } \\
\text { CCPC members). } \\
\text { - Let individual newsrooms address the issue of } \\
\text { corruption. } \\
\text { - Include the issue of media corruption in public } \\
\text { fora involving journalism students and media } \\
\text { practitioners. }\end{array}$ \\
\hline $\begin{array}{l}\text { 2. Eradication of yellow journalism; raising of } \\
\text { audience's standards }\end{array}$ & $\begin{array}{l}\text { - Advocate that Cebuano dailies shift from } \\
\text { sensationalism, particularly in the portrayal of } \\
\text { violence and gender sensitivity. } \\
\text { - Hold discussions with mass audiences to raise } \\
\text { their standards of media consumption, leading } \\
\text { to creation of guidelines upgrading of the } \\
\text { quality of mass-oriented media. }\end{array}$ \\
\hline $\begin{array}{l}\text { 3. Improvement of media's electoral coverage for } \\
\text { voters' education }\end{array}$ & $\begin{array}{l}\text { - Include the opinions and scrutiny of the } \\
\text { grassroots instead of relying only on in-house } \\
\text { political pundits and columnists. } \\
\text { - Give media exposure to political candidates } \\
\text { without money, power, or popularity. } \\
\text { - Give media space for long-standing problems } \\
\text { vs. sensational or passing issues, and solutions } \\
\text { proposed by candidates. } \\
\text { - Conduct electoral monitoring and make results } \\
\text { public. } \\
\text { - Award media that strengthen elections as a } \\
\text { political institution. }\end{array}$ \\
\hline $\begin{array}{l}\text { 4. Periodic internal reviews of CCPC composition } \\
\text { and advocacies }\end{array}$ & $\begin{array}{l}\text { - Conduct strategic planning of CCPC } \\
\text { accomplishments and non-accomplishments, } \\
\text { issues, and plans. } \\
\text { - Review leaders' and members' participation and } \\
\text { change composition, if necessary. } \\
\text { - Evaluate CCPC members' media ethics and } \\
\text { standards prior to implementing a media } \\
\text { literacy campaign. } \\
\text { - Use evaluations to plan and more proactively } \\
\text { pursue other issues for its advocacies such } \\
\text { as peace and order, education of youth and } \\
\text { parents on entertainment media. }\end{array}$ \\
\hline
\end{tabular}




\begin{tabular}{|l|l|}
\hline $\begin{array}{c}\text { Media Self-regulation Issues Taken Up in CCPC } \\
\text { Proactive Advocacies }\end{array}$ & $\begin{array}{c}\text { Stakeholders' Recommendations to Improve } \\
\text { CCPC Proactive Advocacies }\end{array}$ \\
\hline 5. Media critiques with academe and other media \\
advocacy groups & $\begin{array}{l}\text { - Work with entities like CACE, CAMMA, and } \\
\text { Globe Media Excellence Awards to give regular } \\
\text { feedback on local media output, as a local } \\
\text { version of the CMFR and PJR. } \\
\text { - Feature media critiques in the CCPC website } \\
\text { and other online portals. } \\
\text { - Involve netizens and media in conducting } \\
\text { media critiques. }\end{array}$ \\
\hline 6. Continuing education for journalists6. & $\begin{array}{l}\text { Focus on complex issues that media is unable to } \\
\text { explain adequately to the public. } \\
\text { Continuing education for journalists }\end{array}$ \\
$\begin{array}{l}\text { Evaluate media coverage for depth and } \\
\text { relevance. } \\
\text { - Analyze issues perceived as compelling by } \\
\text { media but not needed by the public. }\end{array}$ \\
\hline 7. More engagement of online stakeholders \\
$\begin{array}{l}\text { - Tap social media to raise awareness of CCPC } \\
\text { advocacy on media self-regulation. } \\
\text { - Tap social media to gain more feedback from } \\
\text { citizens and netizens on media self- regulation. } \\
\text { - Amend media practices, procedures, and } \\
\text { guidelines to adjust to the new media (i.e., code } \\
\text { of ethics to address proper monitoring of user- } \\
\text { generated comments). }\end{array}$ \\
\hline
\end{tabular}

Key informants from the academe said that the campaign to expose and stop media corruption should involve also other stakeholders such as teachers and students aspiring to be journalists (Tabada, 2015). Despite the media corruption documentary's limited public viewing and the ensuing controversy stirred up in 2010, it is significant that the academe's interest in and its social engagement with the issue continue after the lapse of four years and intervention of other issues. The effects on the public created by the CCPC documentary Corruption of Media: The Cebu Setting (Cebu Citizens-Press Council, 2010) show the CCPC's strengths and weaknesses in operating as a channel of the Habermasian model of a "public sphere," which represents the inviolate freedoms of assembly, association, and expression. As an institution representing the public and media, the $\mathrm{CCPC}$, in producing the documentary and later showing it to an audience primarily composed of academics and journalists, was able to gather many stakeholders to discuss media corruption. Though the public viewing was limited, it still resulted in controversies among journalists, news sources, and academics (Tabada, 2015). The discussion continued online and exploded exponentially after Pablo John Garcia, as the blogger "Onion-skinned," 
focused on the CСPC and the documentary, drawing even more netizens to discuss the issue. A brother and former consultant on information of Cebu Governor Gwendolyn F. Garcia, Pablo John Garcia pointed out that media organizations like the CCPC and KBP cannot make media self-regulation work because "journalists close ranks" and "fear...offending colleagues" (P. Garcia, personal communication, August 2, 2014). He challenged CCPC members to make a full disclosure so that Cebuanos can decide if the council was just "dominated by cheking Seares and his allies in the media" and "by members of the business sector ... (who) defer to these media giants ... or have business interests themselves and would not want to cross media" (P. Garcia, personal communication, August 2, 2014).

While the media corruption issue illustrated how the CCPC could critically shape public opinion, it also revealed its vulnerabilities. The CCPC and its members were subjected to criticisms by fellow journalists and the blogger Onion-skinned for being hypocritical, malicious, arrogant, and ineffective. For critics, the CCPC manifested the internal divisions of the new media monopoly, with its promotion of corporate and political interests conflicting with the press's promotion of public interest. Even for supporters of the documentary, the CCPC's decision to cut short the dissemination of the documentary and public discussion of the media corruption issue was perceived as submission to pressure from within the industry to stop ventilating an issue that touches off journalists' sensitivity but concerns the public as well.

As stated in its November 16, 2010 resolution, the CCPC perceived that while ventilation of media corruption can be public, the handling of specific cases involving media corruption should, in the spirit of media selfregulation, be handled by the newsrooms according to internal policies and mechanisms.

Table 6 summarizes the key informants' perceptions of the strengths and limitations of the CCPC's media literacy advocacy on media corruption conducted in 2010 through the limited public viewing of the CCPCproduced documentary "Corruption of Media: The Cebu Setting."

Table 6. Strengths and Limitations of the CCPC 2010 Advocacy on Media Corruption. 


\begin{tabular}{|c|c|c|c|}
\hline $\begin{array}{c}\text { Documentary } \\
\text { Features/Aspects }\end{array}$ & What Went Right & What Went Wrong & How CCPC Can Improve \\
\hline \multirow[t]{2}{*}{$\begin{array}{l}\text { 1. Relevance of } \\
\text { media corruption } \\
\text { to Cebu } \\
\text { community }\end{array}$} & $\begin{array}{l}\text { - First local } \\
\text { documentation of } \\
\text { media corruption in } \\
\text { Cebu } \\
\text { - Concerns the public } \\
\text { because of the effects } \\
\text { of media's hidden } \\
\text { conflicts of interest on } \\
\text { news judgment }\end{array}$ & $\begin{array}{l}\text { - } 2010 \text { documentary was } \\
\text { too tame in exposing } \\
\text { media corruption. } \\
\text { - Disappointed viewers } \\
\text { expected a more } \\
\text { courageous exposé of } \\
\text { corrupt journalists in } \\
\text { the documentary. }\end{array}$ & $\begin{array}{l}\text { - To be effective, the } \\
\text { CCPC follow-up of } 2010 \\
\text { documentary should } \\
\text { name erring journalists } \\
\text { - CCPC should support } \\
\text { public discussions } \\
\text { on media corruption } \\
\text { issue: salary scale } \\
\text { is not the problem } \\
\text { but fragmented and } \\
\text { skewed media culture. }\end{array}$ \\
\hline & $\begin{array}{l}\text { - Media corruption } \\
\text { confronts many mass } \\
\text { communication interns. }\end{array}$ & $\begin{array}{l}\text { - Documentary rehashed } \\
\text { rumors and gossip-no } \\
\text { substantiation of its } \\
\text { claims. } \\
\text { - Documentation/ } \\
\text { CCPC's failure to name } \\
\text { corrupt journalists } \\
\text { showed no one was } \\
\text { locally doing this, hence } \\
\text { Garcia's decision to } \\
\text { blog as Onion-skinned } \\
\text { in making his media } \\
\text { exposés. }\end{array}$ & $\begin{array}{l}\text { - Media corruption } \\
\text { campaign should } \\
\text { focus on building } \\
\text { ethical journalists, not } \\
\text { reforming twisted ones } \\
\text { - Campaign on media } \\
\text { corruption must } \\
\text { emphasize media } \\
\text { integrity, transparency, } \\
\text { and accountability. }\end{array}$ \\
\hline $\begin{array}{l}\text { 2. CCPC's decision } \\
\text { to focus on media } \\
\text { corruption in Cebu }\end{array}$ & $\begin{array}{l}\text { - Documentary faced } \\
\text { head-on ethical issue } \\
\text { confronting Cebu } \\
\text { journalists. } \\
\text { - CCPC sent a clear } \\
\text { message that it will } \\
\text { not tolerate erring } \\
\text { colleagues and help } \\
\text { institute reforms. } \\
\text { - Dissatisfaction with } \\
\text { CCPC documentary } \\
\text { made other media } \\
\text { watchdogs (e.g., Onion- } \\
\text { skinned/Pablo John F. } \\
\text { Garcia) blog about the } \\
\text { issue. } \\
\text { - CCPC's stance in } \\
\text { documentary is } \\
\text { consistent with many } \\
\text { local journalists' ethical } \\
\text { practice. }\end{array}$ & $\begin{array}{l}\text { - Documentary made } \\
\text { viewers question if } \\
\text { CCPC was just paying } \\
\text { lip service to police its } \\
\text { own ranks. } \\
\text { - Failure to name names } \\
\text { raised a question if } \\
\text { CCPC was hesitant } \\
\text { to embarrass fellow } \\
\text { journalists. } \\
\text { - CCPC's focus on } \\
\text { Capitol's free meals } \\
\text { to reporters is a "non- } \\
\text { issue." } \\
\text { - CCPC did not touch } \\
\text { on conflicts of interest } \\
\text { involving its own } \\
\text { leaders and members. } \\
\text { - Hypocrisy of media } \\
\text { and CCPC lessened the } \\
\text { credibility of the CCPC } \\
\text { campaign on media } \\
\text { corruption. }\end{array}$ & $\begin{array}{l}\text { - CCPC should be } \\
\text { fearless about exposing } \\
\text { and fighting media } \\
\text { corruption. } \\
\text { - CCPC should sustain } \\
\text { the campaign against } \\
\text { media corruption } \\
\text { because it remains an } \\
\text { industry scourge. } \\
\text { - The academe (teachers } \\
\text { and students) } \\
\text { expressed support } \\
\text { to assist future CCPC } \\
\text { campaigns on media } \\
\text { corruption. } \\
\text { CCPC must reexamine } \\
\text { its individual and group } \\
\text { bias and exert all effort } \\
\text { to transcend those } \\
\text { biases. }\end{array}$ \\
\hline & $\begin{array}{l}\text { - Onion-skinned's posts } \\
\text { reportedly made local } \\
\text { journalists careful } \\
\text { about ethical conduct } \\
\text { so they would not get } \\
\text { mentioned in his blog. }\end{array}$ & & \\
\hline
\end{tabular}




\begin{tabular}{|c|c|c|c|}
\hline $\begin{array}{l}\text { Documentary } \\
\text { Features/Aspects }\end{array}$ & What Went Right & What Went Wrong & How CCPC Can Improve \\
\hline $\begin{array}{l}\text { 3. Generation of } \\
\text { reactions from } \\
\text { Cebu journalists, } \\
\text { politicians, and } \\
\text { citizens }\end{array}$ & $\begin{array}{l}\text { Allowed journalists } \\
\text { to open up about } \\
\text { tolerated erring } \\
\text { practices that create } \\
\text { conflicts of interest or } \\
\text { affect news judgment }\end{array}$ & $\begin{array}{l}\text { Some journalists gave } \\
\text { negative reactions } \\
\text { or overreactions due } \\
\text { to perception that } \\
\text { they were personally } \\
\text { attacked by the } \\
\text { documentary/CCPC. }\end{array}$ & $\begin{array}{l}\text { - Other citizens and } \\
\text { netizens should } \\
\text { monitor and blog about } \\
\text { media corruption since } \\
\text { the CCPC cannot get } \\
\text { to the root of the issue } \\
\text { due to conflicts of } \\
\text { interest. }\end{array}$ \\
\hline & $\begin{array}{l}\text { Documented an open } \\
\text { secret: the discrepancy } \\
\text { between newsroom } \\
\text { standards and informal } \\
\text { culture among some } \\
\text { journalists. } \\
\text { - Stirred up vigorous } \\
\text { online discussion of the } \\
\text { issue and the CCPC } \\
\text { - Onion-skinned posts } \\
\text { about media corruption } \\
\text { became viral. } \\
\text { - Some local journalists } \\
\text { gave insiders' } \\
\text { information about } \\
\text { media corruption to } \\
\text { Onion- skinned. } \\
\text { - Despite the existence of } \\
\text { media corruption, many } \\
\text { citizens still trust local } \\
\text { media. } \\
\text { CCPC's reactions to } \\
\text { Onion-skinned showed } \\
\text { it can be more open } \\
\text { with citizens. }\end{array}$ & $\begin{array}{l}\text { - Blogger Onion-skinned } \\
\text { diminished the quality } \\
\text { of public discourse due } \\
\text { to personal attacks and } \\
\text { conflict of interest. } \\
\text { - Some journalists' } \\
\text { decision to prohibit } \\
\text { public viewing } \\
\text { reflected refusal for } \\
\text { self-examination } \\
\text { and sensitivity to } \\
\text { criticism and public } \\
\text { accountability. } \\
\text { - Traditional journalists } \\
\text { cannot accept criticism } \\
\text { against their behavior } \\
\text { from netizens. } \\
\text { - Netizens claim their } \\
\text { media criticism cannot } \\
\text { be objective, which } \\
\text { for them is the role of } \\
\text { traditional journalists. }\end{array}$ & $\begin{array}{l}\text { - Teachers, students, } \\
\text { netizens, and others } \\
\text { should support the } \\
\text { CCPC in sustaining } \\
\text { the campaign against } \\
\text { media corruption. } \\
\text { - Public discussion of } \\
\text { media corruption } \\
\text { should not be } \\
\text { sensational or personal } \\
\text { but informed and } \\
\text { critical. }\end{array}$ \\
\hline
\end{tabular}




\begin{tabular}{|c|c|c|c|}
\hline $\begin{array}{c}\text { Documentary } \\
\text { Features/Aspects }\end{array}$ & What Went Right & What Went Wrong & How CCPC Can Improve \\
\hline $\begin{array}{l}\text { 4. Effects on } \\
\text { citizens }\end{array}$ & $\begin{array}{l}\text { - The public educated } \\
\text { about local media } \\
\text { lapses. } \\
\text { - Good reason to trust } \\
\text { local media because } \\
\text { it can accept mistakes } \\
\text { and reform. } \\
\text { - Academics praised } \\
\text { the documentary's } \\
\text { impact on Mass } \\
\text { Communication } \\
\text { students and news } \\
\text { interns. } \\
\text { - In classes, documentary } \\
\text { used to discuss ways } \\
\text { students can ethically } \\
\text { handle situations when } \\
\text { PR handlers or others } \\
\text { attempt to corrupt } \\
\text { them during internship. }\end{array}$ & $\begin{array}{l}\text { - The ineffectiveness } \\
\text { of the CCPC in } \\
\text { exposing corrupt } \\
\text { journalists through } \\
\text { the documentary } \\
\text { left a doubt about } \\
\text { their sincerity and } \\
\text { effectiveness in } \\
\text { campaigning for media } \\
\text { self-regulation. } \\
\text { - The documentary's } \\
\text { slant against "corrupt" } \\
\text { Capitol reporters } \\
\text { unfairly portrayed } \\
\text { legitimate Capitol } \\
\text { reporters as being on } \\
\text { the take. } \\
\text { - The documentary } \\
\text { gave the public an } \\
\text { impression that } \\
\text { corruption was } \\
\text { practiced by reporters } \\
\text { but not by editors. }\end{array}$ & $\begin{array}{l}\text { - A CCPC exposé on } \\
\text { media corruption } \\
\text { should spare no one, } \\
\text { especially editors and } \\
\text { media leaders. } \\
\text { - CCPC should make a } \\
\text { follow-up of the } 2010 \\
\text { documentary on media } \\
\text { corruption. } \\
\text { CCPC should continue } \\
\text { advocacy on media } \\
\text { corruption due to } \\
\text { continuing relevance } \\
\text { to journalists, media } \\
\text { interns, and aspiring } \\
\text { journalists. } \\
\text { CCPC should continue } \\
\text { media literacy advocacy } \\
\text { on industry realities to } \\
\text { help prepare students } \\
\text { for ethical conduct as } \\
\text { interns or professionals. }\end{array}$ \\
\hline & & $\begin{array}{l}\text { The documentary kept } \\
\text { the public in the dark } \\
\text { about the conflict of } \\
\text { interest of some CCPC } \\
\text { leaders and members. }\end{array}$ & $\begin{array}{l}\text { - CCPC should work with } \\
\text { CACE, the academe, } \\
\text { and other stakeholders } \\
\text { to expose and fight } \\
\text { media corruption. } \\
\text { - With citizens and } \\
\text { netizens, CCPC can } \\
\text { create a culture against } \\
\text { media corruption. } \\
\text { - Social media must be } \\
\text { tapped in the campaign } \\
\text { against media } \\
\text { corruption. } \\
\text { - In the campaign against } \\
\text { media corruption, the } \\
\text { focus should be on } \\
\text { young and aspiring } \\
\text { journalists. } \\
\text { - Even after Onion- } \\
\text { skinned stopped } \\
\text { posting media critiques, } \\
\text { the field of media } \\
\text { criticism should be } \\
\text { continued by younger } \\
\text { spin busters. } \\
\text { - The CCPC should } \\
\text { be more open with } \\
\text { other media critics, } \\
\text { particularly netizens. }\end{array}$ \\
\hline
\end{tabular}




\section{CCPC's Proactive Mechanism in Media Literacy (ML)}

To equip the public for critical but reasoned analysis and discussion of media issues, the CCPC must consider covering the following fundamentals in its future media literacy campaigns: media history, media and society, media ownership, the news concept, mass media values, press freedom and the public's right to information, and new media. A grasp of media and its interrelationship with governments, elites, and the public will enable citizens and netizens to be more vigilant and effective as media watchdogs (Teodoro, 2002).

Given the legitimacy of CCPC advocacies for media self-regulation and media literacy, a frequently occurring recommendation from key media and public informants is to improve the CCPC's social engagement with citizens and netizens through the use of new media. The CCPC's engagement with print media, broadcast colleagues, and media associations already taps civic and media leaders who not just intellectually accept but voluntarily work for the promotion of the standards of professional excellence and social responsibility in the news media industry.

The challenge faced by the CCPC in sustaining the Habermasian ideal of the public sphere without backsliding into the Bagdikian new media monopoly model is to more aggressively explore the network society, as conceived by Castells, and engage untapped communities of organic intellectuals in its advocacies. Given the blinders of journalists to perceiving their own vulnerabilities and the constraints of the CCPC in being a media critic, the networks of overlapping communities of citizens and netizens present viable alternatives for fulfilling the desire for the "rationalization of power through the medium of public discussion among private individuals" (Habermas, 2006, p. 78). A media-literate citizenry can be a check-andbalance mechanism of reviewing the Cebu press's partnerships with political and business elites to ensure that these do not compromise journalistic independence and integrity.

Aside from involving the grassroots, bloggers, and other netizens as its Cebu stakeholders, the CCPC has yet to fully engage in its present network of media self-regulation and media literacy in Cebu. Aside from unintentionally engaging bloggers like Garcia and purposively working with emerging players like the Cebu Bloggers Society Inc (CBSI), the CCPC should consider key informants' recommendations to engage other digital citizens by including online new organizations in its membership and engaging with journalist-bloggers, digital communities, digital start-ups, aspiring journalists, student bloggers, and other netizens in its advocacies for media self-regulation and media literacy. The CCPC can improve its accessibility to the public by making its website more interactive and 
tapping social media and other new media tools for coverage, feedback, and engagement.

The media literacy campaigns of media advocate groups like the CCPC may empower citizens and netizens to be more active as media watchdogs in three ways: sending of complaints to newspapers and media advocacy groups, posting of online complaints in news websites and social media, and mass self-communication by bloggers and other netizens. Empowered through media literacy, citizens and netizens may resort more to digital engagement with media and no longer need CPCs to act as an alternative grievance channels (Castells, 2010).

On the other hand, key informants also emphasized the reciprocity of the CCPC's engagement with netizens. Even though Garcia became viral in his media critiques as Onion-skinned, he advocated that digital citizens learn the discipline of traditional or mainstream journalism, such as accuracy and fairness. CCPC's media literacy advocacy should not just engage netizens in its advocacies but also involve them in dialogues and learning-by-doing partnerships that focus on exchanges among the practitioners of traditional and new media. Mainstream journalists need digital literacy, which digital journalists and netizens can supply in partnership with the CСPC.

Partnerships between the CCPC and netizens will not just mean strengthening its advocacies of media self-regulation and media literacy but also refining and promoting the nascent field of media studies and media criticism in Cebu. For citizens and netizens to have the expertise, integrity, and credibility to review media, they must be media-literate. Beat journalists and netizens like Garcia criticizing the 2010 CCPC documentary on media corruption questioned the authority and credibility of the sources giving the testimonials on media corruption In Correa's 2009 study of Chilean journalists, the data showed that media workers were more open to selfregulation when the criticism came from socially prominent individuals or sources, as well as fellow journalists, than from people labeled as less educated, less skilled, and less influential. The CCPC's advocacy for media literacy can empower organic intellectuals from civil society to check and balance an increasingly powerful press. The CCPC's partnerships with CMFR, UP Cebu, and St. Theresa's College (STC) to conduct content analysis of local media's electoral coverage in 2007 and 2010 show the potential in tapping mass communication teachers and students to contribute to media studies, which can be used to review and improve Cebu media performance of its work and social obligations ("Coverage of the 2007 election campaign," 2007).

Table 7 synthesizes below the key informants' comments and suggestions to enhance the other media literacy campaigns of the CCPC. 
Table 7. CCPC Media Literacy Advocacies Needing Strengthening or Focus

\begin{tabular}{|c|c|c|}
\hline Media Literacy Issues & $\begin{array}{l}\text { Purpose of the } \\
\text { Advocacy }\end{array}$ & How the CCPC Can Improve \\
\hline $\begin{array}{l}\text { 1. Links between media } \\
\text { ownership and news } \\
\text { treatment }\end{array}$ & $\begin{array}{l}\text { Teach the public how to } \\
\text { critically discern media } \\
\text { messages }\end{array}$ & $\begin{array}{l}\text { - Teach public how media ownership can affect } \\
\text { the type of news/information relayed to the } \\
\text { public. } \\
\text { - Explore how media can be dragged away from } \\
\text { the orbit of the parochial culture or concerns } \\
\text { of media owners and truly build a professional } \\
\text { press. }\end{array}$ \\
\hline $\begin{array}{l}\text { 2. Grassroots-based } \\
\text { media literacy }\end{array}$ & $\begin{array}{l}\text { Democratize all sectors' } \\
\text { access to media }\end{array}$ & $\begin{array}{l}\text { - Conduct an evidence-based campaign to raise } \\
\text { the Cebuano's media literacy. } \\
\text { - Give citizens tools to deal with information } \\
\text { overload and discern values of media messages. } \\
\text { - Understand media standards and learn how to } \\
\text { evaluate media excellence. }\end{array}$ \\
\hline $\begin{array}{l}\text { 3. Involvement of } \\
\text { stakeholders }\end{array}$ & $\begin{array}{l}\text { Continue the conduct } \\
\text { and support of activities } \\
\text { (i.e., CPFW and CCPC } \\
\text { advocacies) that draw } \\
\text { the } \\
\text { participation of many } \\
\text { and varied stakeholders }\end{array}$ & $\begin{array}{l}\text { - Conduct media literacy activities throughout the } \\
\text { year, not just during CPFW. } \\
\text { - Form a protocol between the media, the church, } \\
\text { and other faith communities. } \\
\text { - Continue educating public about the need to } \\
\text { pass the FOI bill. } \\
\text { - Initiate interactions between media, public and } \\
\text { advertisers to tackle unaddressed issues, like } \\
\text { stealth marketing. }\end{array}$ \\
\hline $\begin{array}{l}\text { 4. Institutionalization of } \\
\text { partnerships }\end{array}$ & $\begin{array}{l}\text { Formalize partnerships } \\
\text { to sustain the gains of } \\
\text { media literacy }\end{array}$ & $\begin{array}{l}\text { - Reach out to journalists in other areas to help } \\
\text { start CPCs. } \\
\text { - Expand CCPC membership to or partnerships } \\
\text { with other media advocacy groups. } \\
\text { - Repeat CCPC-Dilaab partnership in } 2013 \text { for } \\
\text { voters' education and conscience formation in } \\
2016 . \\
\text { - Continue corporate partnerships for CCPC } \\
\text { advocacies. } \\
\text { - Partner with DepEd and CHED for creating media } \\
\text { literacy modules and integrating media literacy } \\
\text { in the K to } 12 \text { curricula. } \\
\text { - Partner with CACE to mutually enhance } \\
\text { academic programs on journalism and CCPC } \\
\text { advocacies. }\end{array}$ \\
\hline 5. Digital engagement & $\begin{array}{l}\text { Broaden the reach of } \\
\text { CCPC advocacies }\end{array}$ & $\begin{array}{l}\text { - Tap netizens, especially bloggers, to monitor } \\
\text { news content and act as media watchdogs. } \\
\text { - Make the CCPC website more interactive. } \\
\text { - Get radio stations to cover CCPC quarterly } \\
\text { meetings and activities. } \\
\text { - Get more funding support for CCPC advocacies. } \\
\text { - Include online news organizations in CCPC's } \\
\text { membership. }\end{array}$ \\
\hline
\end{tabular}




\begin{tabular}{|c|c|c|}
\hline Media Literacy Issues & $\begin{array}{c}\text { Purpose of the } \\
\text { Advocacy }\end{array}$ & How the CCPC Can Improve \\
\hline & & $\begin{array}{l}\text { - Initiate dialogues between mainstream and } \\
\text { digital journalists to learn from each other. } \\
\text { - Use digital tools to help media self-regulation. } \\
\text { - Involve new media players that are not yet } \\
\text { involved with CCPC, i.e., istorya.net and Mynimo. } \\
\text { - Make CCPC advocacies more public and } \\
\text { accessible through mini-online conferences and } \\
\text { livestreaming. }\end{array}$ \\
\hline 6. Digital literacy & $\begin{array}{l}\text { Help educate and } \\
\text { professionalize new } \\
\text { media players, as well } \\
\text { as educate mainstream } \\
\text { journalists about new } \\
\text { media }\end{array}$ & $\begin{array}{l}\text { - Continue partnership with CBSI for trainings on } \\
\text { media standards. } \\
\text { - Partner with UP Cebu's Center for Media } \\
\text { Education for media literacy. } \\
\text { - Tap netizens and new media players to give } \\
\text { new media literacy trainings to mainstream } \\
\text { journalists. }\end{array}$ \\
\hline 7. Preference for youth & $\begin{array}{l}\text { Reach out to youth } \\
\text { leaders, younger media } \\
\text { practitioners and other } \\
\text { youths who are in touch } \\
\text { with digital trends }\end{array}$ & $\begin{array}{l}\text { - Train youths about traditional and new media. } \\
\text { - Outreach to youth must involve a year-round } \\
\text { effort or network that extends beyond CPFW. } \\
\text { - CCPC's participation in national and international } \\
\text { gatherings on media should be cascaded as } \\
\text { learnings for the public, especially the youth. } \\
\text { - Engage the youth through social media. } \\
\text { - Lobby with schools to offer media literacy } \\
\text { courses. } \\
\text { - Through media literacy modules applied in } \\
\text { campuses, help prevent online bullying, stalking, } \\
\text { and other digital abuses. }\end{array}$ \\
\hline
\end{tabular}

In conclusion, this study shows that the initiation and promotion of media self-regulation in Cebu begins with the newsroom practice of enforcing professionalism and public stewardship, and is promoted by the culture of media accountability fostered by media advocacy groups such as the CCPC, and local traditions such as the annual Cebu Press Freedom Week, both of which involve the media and various stakeholders from the public sector. Media self-regulation can be enhanced, balanced, and sustained through media literacy, which ensures greater participation of citizens and netizens as media watchdogs and defenders of freedom of expression. To broaden social engagement of its reactive and proactive advocacies and empower the grassroots and other peripheries for more participation in governance, particularly media self-regulation, media advocacy groups like the CCPC should include the digital portal and its stakeholders. 


\section{References}

About the PPI. (n.d.). Retrieved from https://philpressinstitute.net/about-ppi/

Article 19 \& Center for Media Freedom and Responsibility. (December 2005). Freedom of expression and the media in the Philippines. London \& Manila: Article 19 \& CMFR.

Bagdikian, B. H. (2004). The new media monopoly. Boston: Beacon Press.

Basilan, R. S. (2011). A walk to remember: 17 years of Cebu Press Freedom Week, unity and fighting for rights. Cebu Journalism \& Journalists, 6, 13-17.

Bengco, R. (2011, October 2). The Philippine Press Council: Surviving the challenges. Philippine Press Institute. Retrieved from https://reginabengco.wordpress.com/2011/10/02/the-philippine-presscouncil-surviving-the-challenges/

Castells, M. (2010). Communication power: Mass communication, mass self- communication, and power relationships in the network society. In. J. Curran (Ed.), Media and Society (pp. 3-15). London and New York: Bloomsbury.

Cebu Citizens-Press Council. (n.d.). About CCPC. Retrieved from http://www.cebucitizenspresscouncil. org/about/

Cebu Citizens-Press Council (Producer). (2010, September). Corruption of media: The Cebu setting [Video documentary]. Philippines: ImaGEWorks

Cebu journalists: A lot to thank for. (2006). Cebu Journalism \& Journalists, 2, 6-7.

Cebu press freedom week. (2013). Cebu Journalism \& Journalists, 8, 22-24.

Cebu press freedom week through the years. (2004). Cebu Journalism: The People and the Times, 1, 54-55.

Cebu Press Freedom Week Timeline". (2012). Cebu Journalism \& Journalists, 7, 13-15.

Center for Media Freedom and Responsibility. (2011, May-June). Does self-regulation have a future in the Philippines? Philippine Journalism Review (PJR) Reports, 10-11.

Correa, T. (2009, Autumn). Does class matter? The effect of social class on journalists' ethical decision making. Journalism and Mass Communication Quarterly, 86(3), 654-672.

Coverage of the 2007 election campaign in Cebu's three English and two Bisaya dailies. (2007). Cebu Journalism \& Journalists, 3, 8-9.

Cuizon, E. M. (2014). What do you know, Cebu Press Freedom Week started in 1984. Cebu Journalism \& Journalists, 9, 26-30.

De Jesus, M. Q. (2002). Press freedom and responsibility. In C. C. A. Balgos (Ed.), Watching the watchdog: Media self-regulation in Southeast Asia (pp. 2-10). Bangkok, Thailand: Friedrich-Ebert-Stiftung.

De Jesus, M. Q., \& Khan, R. E. (2005). In search of solutions: A study of journalist killings in the Philippines, 2000-2005. Philippine Journalism Review, 12-15.

Elumbre, V. L., \& Tuazon, J. T. (2005, September-October). Citizens press councils: Making media more responsive and responsible. Philippine Journalism Review (PJR) Reports, 16-17.

Elumbre, V. L. (2006a, January). The Cebu Citizens-Press Council: Giving the public a role in media. Philippine Journalism Review (PJR) Reports, 9 (issue), 9.

Elumbre, V. L. (2006b, October). Revving up the Cebu Citizens-Press Council: Dealing with grievances against media. Philippine Journalism Review (PJR) Reports, 16-17. 
Habermas, J. (2006). The public sphere: An encyclopedia article. In M. G. Durham \& D. Kellner (Eds.), Media and cultural studies: Keyworks (pp. 73-87). Malden, MA and Oxford, UK: Blackwell Publishing.

Kapisanan ng mga Brodkaster ng Pilipinas. (n. d.). Retrieved from https://www.kbp.org.ph/responsiblebroadcasting.

Katigbak, E. O. (2002). A journalism review. In C. C. A. Balgos (Ed.), Watching the watchdog: Media selfregulation in Southeast Asia (pp. 102-105). Bangkok, Thailand: Friedrich-Ebert-Stiftung.

Lim, C. A. T. (2010). Cebu Citizens-Press Council: Forging a more responsible, safe and dynamic press. Cebu Journalism \& Journalists 5, 63-64.

Lim, C. A. T. (2013). The advocate. Cebu Journalism \& Journalists, 8, 54.

Lim, C. A. T. (2014). Going places, growing voices. Cebu Journalism \& Journalists, 9, 36-38.

Macale, H. B. L. (2003, February). Regional press councils get busy. Philippine Journalism Review, 14(1), 19-20.

Macale, H. B. L. (2004, January). Broadcast self-regulation: By KBP or by the station itself? Philippine Journalism Review, 15(1), 26-27.

Mariano, D. (2002). Reigning in a rough and rowdy press. In C. C. A. Balgos (Ed.), Watching the watchdog: Media self-regulation in Southeast Asia (pp. 64-72). Bangkok, Thailand: Friedrich-Ebert-Stiftung.

Miranda, M. R. B. (2002a, June). Watching the watchdog: Local press councils hope to make a difference. Philippine Journalism Review, 13(3), 36-39.

Miranda, M. R. B. (2002b, August). Press councils update: Landmark achievement. Philippine Journalism Review, 13(4), 33.

Parco, B. A. (2011). A breed apart: Lessons for community media from Cebu. Cebu Journalism \& Journalists 6, 29-31.

Pinlac, M. Y. (2007, September 1). The martial law-era editors look back: Marcos and the press. Center for Media Freedom and Responsibility. Retrieved from https://cmfr-phil.org/media-ethicsresponsibility/ethics/marcos-and-the-press/

Reader, B. (2006, Winter). Distinctions that matter: Ethical differences at large and small newspapers. Journalism and Mass Communication Quarterly, 83(4), 851-864.

Seares, P. A. (2012). Ad hoc convenor, continuing board. Cebu Journalism \& Journalists, 7, 15.

Singer, J. B. (2005). The political j-blogger:"Normalizing" a new media form to fit old norms and practices. Journalism, 6(2), 173-198.

Sun.Star Cebu. (2004). Sun.Star Code of Standards and Ethics (2nd ed.). Cebu City: SunStar Publications, Inc.

Tabada, M. T. Q. (2013). Raul del Mar: Moving for media. Cebu Journalism \& Journalists. 8, 27-28.

Tabada, M. T. Q. (2015). Media self-regulation through media literacy: insights from the Cebu Citizens-Press Council (CCPC) (Unpublished master's thesis). University of the Philippines Diliman, Quezon City, Philippines.

Teodoro, L. V. (2002). Empowering the public. In C. C. A. Balgos (Ed.), Watching the watchdog: Media selfregulation in Southeast Asia (pp. 134-140). Bangkok, Thailand: Friedrich-Ebert-Stiftung.

Timeline: Cebu Press Freedom Week. (2010). Cebu Journalism \& Journalists, 5, 56-57.

Timeline: Cebu Press Freedom Week through the years. (2011). Cebu Journalism \& Journalists, 6, 18-21. 


\section{Note}

${ }^{1}$ The original study was funded by a UP Cebu research grant and was accepted as a thesis for a Master of Arts in Journalism degree at the University of the Philippines (UP) Diliman in 2015. The findings were presented as a paper at the Asian Congress for Media and Communication (ACMC) 2016 International Conference; the Cebu Association of Communication Educators (CACE) 2016 First Research Conference; and the Cecilia Lazaro Kritika Series for Sining del Pilar 2018: Ituloy ang Kwento.

MA. THERESA ANGELINA Q. TABADA is an assistant professor of the College of Communication, Art, and Design (CCAD) at the University of the Philippines (UP) Cebu. She represented the academe in the Cebu Citizens-Press Council (CCPC) from 2005 to 2012, but was already on leave when she studied the CCPC for her masteral thesis. Her special reports and essays have won journalism awards. She writes an editorial-page column and editorial for SunStar Cebu. She has a Bachelor in Communication Arts degree from UP Cebu and a Master of Arts in Journalism from UP Diliman. She is enrolled in the Ph.D. Media Studies Program of the College of Mass Communication in UP Diliman. (Corresponding author: mayette. tabada@gmail.com) 